San Jose State University

SJSU ScholarWorks

Master's Theses

Master's Theses and Graduate Research

1990

\title{
Teachers' self concept, their acceptance of others, and achievement of their elementary school children
}

Sandra G. McMahan

San Jose State University

Follow this and additional works at: https://scholarworks.sjsu.edu/etd_theses

\section{Recommended Citation}

McMahan, Sandra G., "Teachers' self concept, their acceptance of others, and achievement of their elementary school children" (1990). Master's Theses. 3331.

DOI: https://doi.org/10.31979/etd.saps-tkc4

https://scholarworks.sjsu.edu/etd_theses/3331

This Thesis is brought to you for free and open access by the Master's Theses and Graduate Research at SJSU ScholarWorks. It has been accepted for inclusion in Master's Theses by an authorized administrator of SJSU ScholarWorks. For more information, please contact scholarworks@sjsu.edu. 


\section{INFORMATION TO USERS}

The most advanced technology has been used to photograph and reproduce this manuscript from the microfilm master. UMI films the text directily from the original or copy submitted. Thus, some thesis and dissertation copies are in typewriter face, while others may be from any type of computer printer.

The quality of this reproduction is dependent upon the quality of the copy submitted. Broken or indistinct print, colored or poor quality illustrations and photographs, print bleedthrough, substandard margins, and improper alignment can adversely affect reproduction.

In the unlikely event that the author did not send UMI a complete manuscript and there are missing pages, these will be noted. Also, if unauthorized copyright material had to be removed, a note will indicate the deletion.

Oversize materials (e.g., maps, drawings, charts) are reproduced by sectioning the original, beginning at the upper left-hand corner and continuing from left to right in equal sections with small overlaps. Each criginal is also photographed in one exposure and is included in reduced formin at the vack of the book.

Photographs included in the original manuscript have been reproduced xerographically in this copy. Higher quality 6" $\mathrm{x} 9$ " black and white photographic prints are available for any photographs or illustrations appearing in this copy for an additional charge. Contact UMI directly to order.

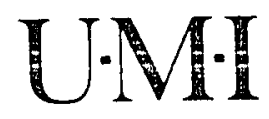


Order Number 1341682

Teachers' self concept, their acceptance of others, and achievement of their elementary school children

McMahan, Sandra Gull, M.A.

San Jose State University, 1990

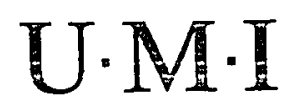


TEACHERS' SELF CONCEPT, THEIR ACCEPTANCE OF OTHERS, AND ACHIEVEMENT OF THEIR EIEMENTARY SCHOOL CHILDREN

\author{
A Thesis \\ Presented to \\ The Faculty of the Department of Teacher Education \\ San Jose State University \\ In Partial Fulfillment \\ of the Requirements for the Degree \\ Master of Arts
}

By

Sandra G. McMahan

August, 1990 

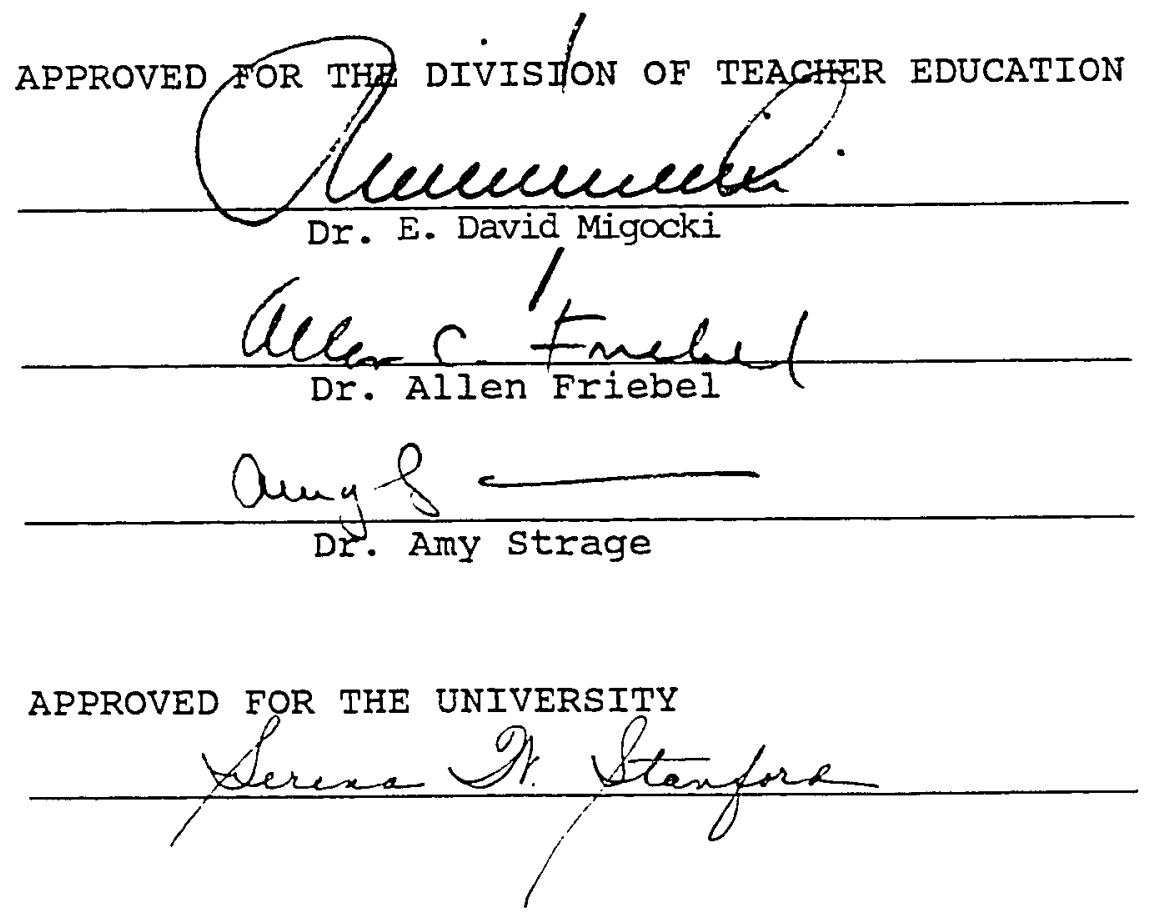


\section{ABSTRACT}

TEACHERS' SELF CONCEPT, THEIR ACCEPTANCE OF OTHERS, AND ACHIEVEMENT OF THEIR ELEMENTARY SCHOOI CHILDREN

\section{by Sandra G. McMahan}

This study examines the interrelationship between teacher self-concept, acceptance of others and achievement of elementary school children.

The research questions in this study were: 1) What is the relationship between teacher self-concept and student achievement? 2) What is the relationship between teacher acceptance of others and student achievement? 3) How do teacher self-concept and acceptance of others compare in their relationship to student achievement?

Fourth-grade teachers from $A Y$ 1988-89 were administered a self-concept scale and a social distance scale. Achievement scores for their 1988-89 fourth-grade students were taken from district administered spring, 1989, achievement tests. The data were analyzed using the Spearman Rank order Correlation coefficient in order to determine the interrelationship between teactiar self-concept, acceptance of others and student achievement. The correlations obtained were low; however, the low correlations do not rule out that there is a relationship. Results of the study are important, for they suggest ways to search for such a relationship. 


\section{Dedication}

I dedicate this thesis to my husband, Jack, and to my four children, Jack, Kristie, Heather and Becky whose encouragement, support, and caring made it possible.

$$
\text { and to }
$$

Dr. David Migocki who served as an inspiration for this study and provided me with the necessary confidence. 


\section{Acknowledgements}

A number of individuals contributed in important ways to the completion of this thesis. I would like to express my appreciation to each one.

First I would like to thank the administrators, teachers and fourth-grade students of the sample school district who participated in this study.

To my Aunt Martha and Uncle Ray I owe a very special note of appreciation for their warm hospitality and generosity in allowing me to stay with them while the study was being conducted.

I would like to thank my thesis advisor, Dr. David Migocki, for guiding me through each phase of writing the thesis. Without his patience and dedication, this study would not have been possible.

I would like to express my appreciation to Dr. Allen Friebel and Dr. Amy strage. Their knowledge and expertise greatly added to the clarity of the study. 


\section{Table of contents}

Page

signature Page..........................i

Abstract..............................

Dedication Page......................... iv

Acknowledgements......................... v

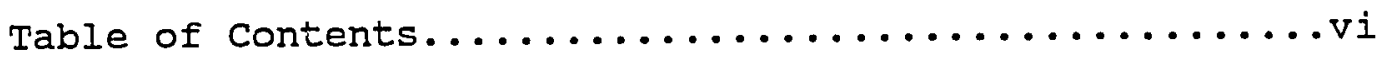

Iist of Tables..........................

List of Figures............................

Chapter

I INTRODUCTION

Introduction.......................

setting for the study.................. 3

Research Problem statement.............. 6

Research Purpose statement.............. 7

Hypotheses........................ 7

operational Definitions................ 7

Assumptions........................

Limitations...................... 8

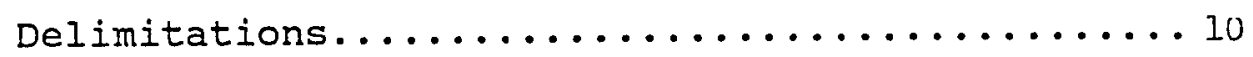

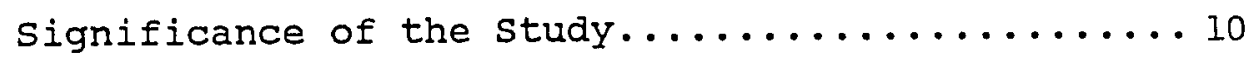

II THE RELATED IITERATURE

Introduction........................ 11 
Methodology........................ 11

Review of Relevant Literature............. 13

Relationship Between Student self-Concept and

Student Achievement.................. 13

Relationship Between Teacher Behavior and

student self-Concept.................. 15

Relationship Between Teacher Behavior and

student Achievement................. 16

Relationship Between Teacher Behavior and

Teacher Self-Concept and Teacher Acceptance

of others...................... 17

Relationship Between Teacher Self-Concept and

student self-concept.................. 17

Relationship Between Teacher self-Concept and

Student Achievement.................. I9

Relationship Between Teacher Acceptance of

Others and student self-Concept...........20

Relationship Between Teacher Acceptance of

others and student Achievement........... 23

Relationship Between Teacher Self-Concept and

Acceptance of others.................. 24

summary........................... 27

vii 
III RESEARCH DESIGN/METHODOLOGY

Introduction........................ 29

Hypotheses........................... 29

Research Design...................... 30

Research Universe and Sampling Procedures...... 30

Total student Population.................. 30

Total Teacher Population................ 31

Salient Characteristics of Both the Universe

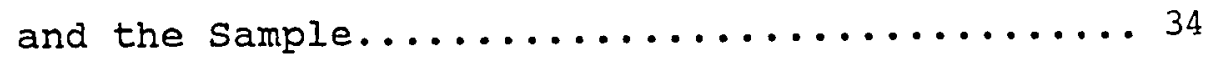

Specification of the sufficiency of the sample

selected.......................... 34

Data-Gathering Tools/Instrumentation.......... 38

Tools Used to Collect Relevant Data......... 38

Brief synopsis of the Tools.............. 38

Provisions for validity and Reliability...... 40

Procedures for Collection of the Data.........4 4

Application of the Data-Gathering Tools to the

Sample Population....................41

Provisions for Assuring Uniformity/Reliability

in the Collection of the Data............ 42

Provisions for Codifying the Mailed Instru-

ments and Follow Up.................43

viii, 
Procedures for Analysis of the Data..........44

Explanation of the Statistical Devices Used on the Data and Their Suitability for the Purpose Intended.......................44

IV $\quad$ RESULTS............................ 45

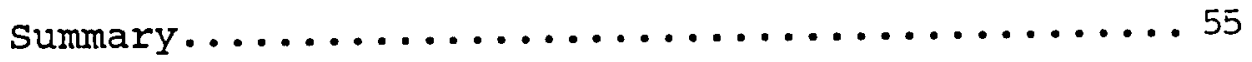

$\mathrm{V}$ SUMMARY, CONCLUSIONS, RECOMMENDATIONS......... 57

summary............................ 57

Conclusions.........................61

Recommendations...................... 65

VI REFERENCES.......................... 69

VII APPENDICES............................. 78

Appendix A: Teacher Questionnaire..........78

Appendix B: Tennessee Self-Concept Scale...... 79

Appendix C: Bogaraus Social Distance Scale.... 86

Appendix D: Human Subjects Protocol for Research 92

Appenaix E: Cover Letter............... 98

Appendix F: Consent Form................99

Appendix G: Instructions for the TSCS and the

Bogardus Social Distance Scale.....102

Appendix H: Political and Economic Distance Definitions.....................104

Appendix I: Raw scores....................107 


\section{List of Tables}

Table

Page

1 Teacher Questionnaire Results...................

2 Ranking of Teachers on Scales and student Test Scores from Lowest value to Highest Value........35

3 Teacher Sample and student Sample Test Results....48

4 Spearman Rank order Correlation Coefficients.....51 


\section{List of Figures}

Figure

Page

I Model Underlying Present Study............. 4

2 Sample profile score of one Teacher on the Tennessee self-Concept scale..............46

3 Tennesee Self-Concept scale Total score Percentile Against the Iowa Test of Basic Skills Class National Percentile Ranking................ . . 50

4 Bogardus Social Distance Scale Score Against the Iowa Test of Basic Skills Class National Percentile Ranking..................... 54 
CHAPTER I

Introduction

Let people realize clearly that every time they threaten someone or humiliate or hurt unnecessarily or dominate or reject another human being, they become forces for the creation of psychopathology, even if these be small forces. Let them recognize that every man who is kind, helpful, decent, psychologically democratic, affectionate and warm, is a psychotherapeutic force even though a small one.

\section{Abraham Maslow}

A teacher's effectiveness in promoting student achievement is dependent on several factors. Some of these factors are environmental. For example, a teacher's effectiveness is severely hampered without adequate supplies or equipment or if the class size is too large. other factors are personal, such as the ability to organize and communicate concepts clearly. This study examines what role, if any, two other personality traits play in teacher effectiveness: teacher self-concept and acceptance of others. These traits are of particular interest because, like the ability to organize and communicate concepts clearly, they can be enhanced through teacher education (Reed and Goetz, 1980).

A relationship between teacher self-concept and student achievement is suggested by several studies which have focused on the role of the student's own self-concept in achievement. It seems clear that there is a strong 
positive correlation between student self-concept and achievement, and that the student's self-concept is influenced by feedback from significant others (such as family members, peers, and teachers) as well as feedback from achievement itself. In examining the role of the teacher in influencing the students' self-concept, Staines (1958) concluded that changes in student self-concept do occur as an outcome of the learning situation and that teachers with healthy self-concepts provide positive learning environments. Curtis and Altman (1977) reported that teachers with high self-concept tend to have students with high self-concepts.

A relationship between teacher acceptance of others and student achievement is also suggested by studies which have examined the role of student self-concept and achievement. For example, Purkey (1970) found that a student's self-concept is enhanced by treatment that telis the student he/she is good. Thus, if a student is accepted by the teacher, the student's self-concept is enhanced which, in turn, may enhance achievement. Indeed, a study by Brenneman, Willower, and Lynch (1975) suggested that acceptance of others is more highly related to student achievement than teacher self-concept.

If teacher self-concept and acceptance of others do play a role in student self-concept and achievement, they most likely do it through teacher behavior. For example, 
a study by Cantrell, stenner, Jackson, and Katzenmeyer (1977) illustrated that it is possible to link teacher acceptance of others to teacher attitude and the positive feedback teachers give to the students. According to Schultz (1986), Rogers (1961) assigns the self-concept a central place in personality theory and suggest that the individual's self-concept is a major factor influencing his behavior.

The relationship between teacher self-concept and acceptance of others and student achievement as suggested by the above studies is summarized in Figure 1 (see next page). Studies have suggested that teacher self-concept (TSC) is correlated to teacher acceptance of other (TAO). Teacher self-concept and teacher acceptance of others have been shown to be reflected in teacher behavior (TB). Teacher behavior, in turn, has been shown to affect student self-concept (SSC) and consequential student achievement (SA). Research has also indicated a strong interaction between student self-concept and student achievement.

\section{setting for the study}

The sample school district for this research was selected because it is located in a small midwestern American city (aistrict population $=108,307$ ), where the researcher could potentially use the entire fourth-grade population as the sample. 


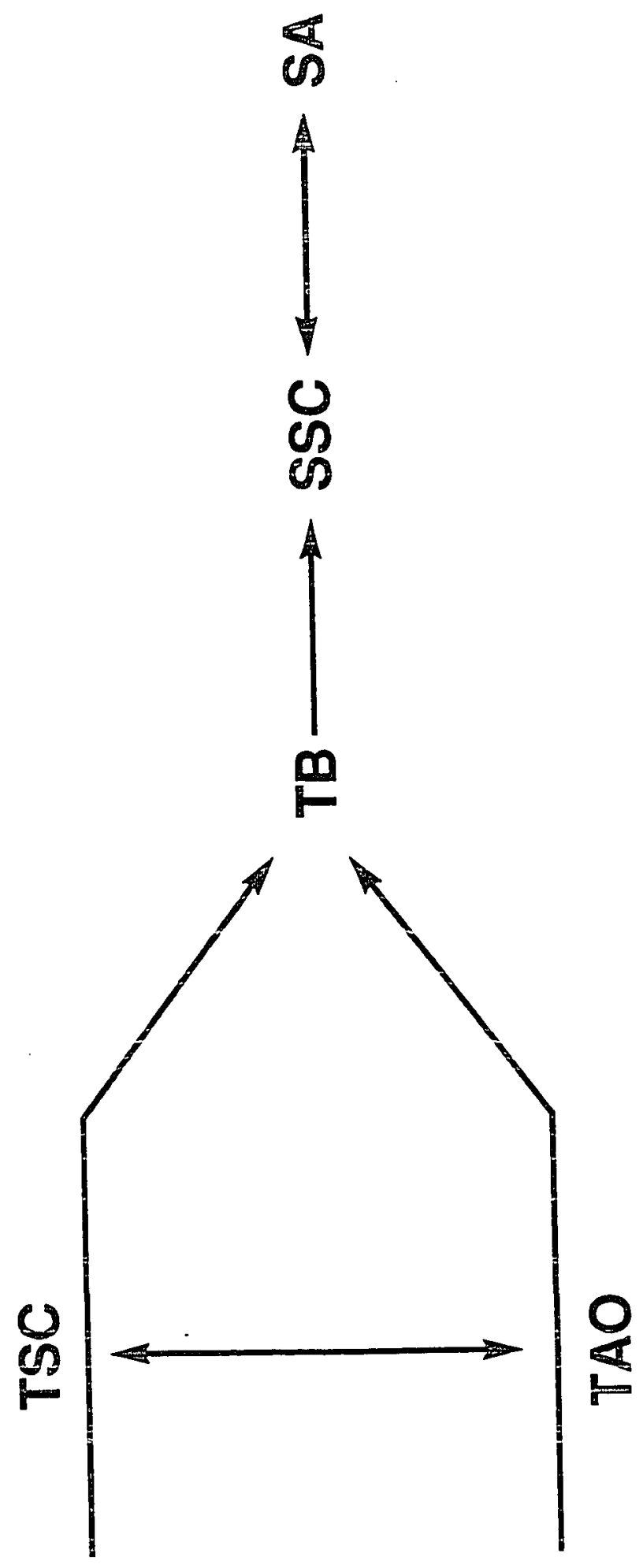

풍

๑.

허은

তิ

중도

을

॥ะ क

등

$\circlearrowleft$ 임

E

>는

을

心斻

运的要

ब

Ф吾的

능ำ

잉

=엉

는

응용ㅇㅇ

品

ธ。

응

능

-10

Q

궁어

证的 
The study was conducted using fourth grade students in order to eliminate variables which are associated with the earlier years of schooling, such as initial adjustment. In support of using fourth grade was a study by campbell (1967). According to Campbell, it appears likely that attention to the development of a high level of self-esteem is more significant to achievement in fourth, fifth and sixth grades. Although he does not suggest a reason, it is possible that this situation results because the degree of dependence on the teacher as a significant person might decrease as the student proceeds beyond the elementary school years. A second reason for not using students in higher grades is that the social adjustments associated with the pubescent years could impact on the results of the study.

The relevant demographics of the city compared to the average American city are as follows:

\section{The city \\ (Director of Research of District) \\ (Food Service Manager of District)}

$\begin{array}{lcc}\begin{array}{l}\text { Qualifying } \\ \text { for free or } \\ \text { reduced-rate } \\ \text { lunches }\end{array} & 26.83 \% & 46.7 \% \\ \begin{array}{l}\text { Dropout rate } \\ \text { Minority popu- }\end{array} & 7.0 \% & 26.9 \% \\ \text { lation } & 12.0 \% & 21.4 \%\end{array}$

Average American City (1990 World Almanac)

$46.7 \%$ 
The district did not have a significant minority population (only 12\%), nor did it have an unusually high number of disadvantaged families (26.83\%). Out of a total of 5,571 1988-89 secondary school students, 368 (7\%) withdrew before graduation or completion of a secondary program for reason(s) other than death or transfer to any other approved secondary school program. Since most of the families were middle-class Anglos, factors (e.g., poverty, minority status) which might influence the results of the findings were minimized.

Research Problem Statement

Research (Berger, 1952; Sheerer, 1949) has indicated that teachers' behavior can be affected by their self-concept and their acceptance of others. It has also been suggested that teacher behavior affects student self-concept and, as à consequence, student achievement (Reed \& Goetz, 1980).

If the foregoing findings/assertions are correct, then one might expect to find a significant correlation between teacher self-concept/acceptance of others and student achievement. Thus far, no comprehensive study of this type has been conducted, i.e., there have been no studies to date simultaneously focusing on these three variables. It is this gap which the present study attempts to fill. 


\section{Research Purpose Statement}

The purpose of this study was to determine whether a teacher who has a good self-concept is also likely to accept others and exhibit a humane, person-oriented stance toward students. It was designed to discover if students, in return, would feel prized and thus perform better academically. It was anticipated that if there were a strong positive correlation between teacher self-concept/acceptance of others and student achievement, results of the research would indicate the advisability of educating teachers about the importance of those factors, and, as a by-product, increase levels of student achievement and lessen the student dropout rate for the sample school district.

\section{Hypotheses}

Three hypotheses were subjected to empirical verification in the present study:

1. Student achievement is positively related to teacher self-concept.

2. Student achievement is positively related to teacher acceptance of others.

3. There is a higher correlation between teacher acceptance of others and student achievement than between teacher self-concept and student achievement.

operational Definitions

1. Good self-concept: the possession of behavior 
patterns guided by internalized values, a sense of self-worth, accepting one's recognized faults, and an absence of shyness or self-consciousness (Wylie, 1969; Brenneman et al., 1975). 2. Acceptance of otiners (Social Distance): the degree of sympathetic understanding that exists between two persons or between a person and a group (Bogardus, 1966).

\section{Assumptions}

1. The Tennessee Self-Concept scale (Roid and Fitts, 1988) is a valid indicator of self-concept.

2. The Bogardus Social Distance Scale (Bogardus, 1966) is a valid indicator of teacher acceptance of others. 3. The same achievement tests, which were selected by the school system's administrative office, are administered uniformly to all fourth grade students in the selected school district.

4. Teachers will answer the questions regarding self-concept and acceptance of others honestly. 5. Students taking the achievement tests have been in good physical health, and not suffering from other conditions which could hinder their performance. 6. The physical testing conditions, i.e., lighting, temperature, time of day will be consistent and appropriate for all participants.

\section{Iimitations}

1. Teachers might not be willing to complete the 
self-concept and acceptance of other surveys because of the time involved or because of what they might expose about themselves.

2. The teachers might not make the effort to think through their true feelings on the self-acceptance and acceptance of others questions for an accurate measure of how they feel.

3. In answering questions on the various test instruments, teachers might be affected by their feelings caused by the events of that day. Their answers, thus, may not be representative of their feelings over a longer period of time. 4. Since teachers were aware that the study concerned their self-concepts and acceptance of others, they might respond to their ideal self-concept and attitude rather than their real self-concept and attitude. 5. The researcher had no control over the kind of achievement test or the administration of the achievement tests given to the students. While the Iowa Test of Basic skills (I.T.B.S.) is a reputable index of student achievement, there may be skills not measured on the test which are more greatly affected by the affective aspects of the classroom environment, i.e., student interest in exploring knowledge.

6. Self-Concept and Acceptance of others are ambiguous terms and were therefore difficult to assess 
quantitatively.

7. This design had the limitation that since random assignment of students to teachers was not applied, the equivalence of the classes was not assured.

\section{Delimitations}

1. Thirty-one teachers of the 1988-89 fourth grade cohorts volunteered for the study. There were approximately twenty-five students per class. The teacher sample and student sample for the study were large enough to give confidence to the findings. 2. The Tennessee Self-Concept Scale was employed in the measurement of the first variable, teacher self-concept. 3. The second variable, acceptance of others, was measured by the Bogardus Social Distance Scale.

\section{Significance of the study}

A detailed knowledge of the factors that influence student achievement is requisite to devising ways to enhance it. No doubt the teacher plays a crucial role in student achievement. This study examined specifically, for the first time, the relationship of two teacher personality traits, self-concept and acceptance of others, to student achievement. 
CHAPTER II

The Related Literature

From a psychotherpeutic point of view, teaching is basically an interpersonal relationship, which, with its proper techniques and devices, helps reduce or control anxiety and so promotes learning.

\section{William stavsky}

The researcher hypothesized the following:

1. Student achievement is related to teacher self-concept.

2. Teachers' acceptance of others is related to student achievement.

3. There is a higher correlation between teacher acceptance of others and student achievement than between teacher self-concept and student achievement.

\section{Methodology}

The author initially used three computerized searches to obtain a comprehensive review of the literature. These included a DIAIOG search of ERIC Data Base and a DIALOG search of PSYchINFO.

In order to implement the computerized searches, the author identified her specific topic in her own terms. This topic was then translated into the following descriptors: teacher self-concept, student achievement, elementary school, teacher characteristics, pupil control ideology, teacher-student interaction, school 
environment. The author used the Rotated Descriptor Display in the back of the ERIC Thesaurus to help identify the descriptors. After making a list of the best descriptors, the researcher then located them in the Alphabetical Descriptor Display in the main part of the Thesaurus. The researcher then proceeded to check the broader terms, narrower terms, and related terms under the descriptors and identified possible other descriptors relevant to the chosen topic.

After making a final list of the descriptors most likely to have been used to represent the topic, the author followed the directions of the particular library or information retrieval system for a search of the database. This necessitated going back to 1952 in order to obtain the pertinent information available from books, journals, unpublished dissertations, microfilms and microfiche.

For the manual search, the author looked under the selected descriptors in the subject Index of Resources in Education (R.I.E.) and current Index to Journals in Education (C.I.J.E.) to find titles relevant to her search. The author also used the Library of congress Card Catalogue.

In addition to hand searches and computer searches, the author interviewed several administrators in the selected school district. These interviews, as well as 
the demographics provided by the sample school district and the CACI's 1988 Sourcebook of Demographics and Buying Power for Every Zip code in the U.S.A., provided information about the number of minority and disadvantaged students in the school district, and gave other pertinent information concerning the teachers and the school district.

Review of the Relevant Literature

Research provides evidence that teacher self-concept and acceptance of others are linked to student achievement through student self-concept (see Figure 1). As one will note in the following review, the boundaries are not always distinct between these variables. Relationship Between student self-Concept and student Achievement

Campbell (1967) reported that for fourth, fifth and sixth grade students, there is a positive relationship between performance on Coopersmith's Scale for Self Esteem and achievement scores. Although most researchers [Combs, Blume \& Wass (1974), Franks \& Dillon (1976), Coleman (1966) J agree that there is a clear and strong correlation between self-concept and achievement, it is not clear whether one causes the other or whether, indeed, they are both caused by something else. Do students do well because they think well of themselves or think well of themselves because they do well? on the one hand coleman 
(1966), in his classic report on educational opportunity, maintained that the relation of a student's self-concept to achievement is "from one perspective, merely the accuracy of his estimate of his scholastic skills, and is probably more a consequence than a cause of scholastic achievement" ( $p$. 24). On the other hand, combs et al. (1974) found evidence that self-concept may actually precede achievement in school. They found that kindergarteners' self-concept (presumably formed before they had much opportunity to experience academic success or failure) were strongly predictive of their academic achievement in both first and sixth grades. Purkey (1970) cited research by Lamy that revealed a similar correlation for kindergarteners. Nevertheless, Purkey, himself, believed that the evidence was inconclusive. He stated that the basic question of whether children see themselves negatively because of their poor school performance, or whether they perform poorly in school because they see themselves negatively is unresolved. purkey postulated a continuous interaction between self-concept and achievement. Franks and Dillon (1976) offered a similar interpretation:

In sum, self-esteem is relevant not only because it is an unseparable part of academic performances...but because of its empirical association with a broad range of abilities that relate to the child's state of mental health, i.e., as a whole psyche. (p. 35) 
Relationship Between Teacher Behavior and student

\section{Self-Concept}

Franks and Dilion (1976) noted that there are two

sources for a child's self-esteem: the feedback a child gets from observing the effect of his or her owin actions and the feedback the child gets from significant others. The feedback people get from others has stronger effects on self-esteem than the feedback that comes from merely acting in the world. Teachers communicate this sort of feedback to students through grades, test scores, verbal and the more subtle non-verbal responses.

Cheong and wadden (1978) demonstrated that dogmatic behavior towards control (which is attributed to teachers with low self-concept) is correlated to poor pupil self-concept. The purpose of their study was to examine teacher's effect on fourth-, fifth-, and sixth-grade pupils' self-concept when the students were taught by two extreme, significantly different groups of teachers: one group as the most experimental or the least dogmatic, and the other as the least experimental or the most dogmatic. Pupils who were taught by the most experimental group of teachers had significantly higher self-concept than pupils who were taught by the least experimental group of teachers. They concluded that since the personality of the teacher makes a difference in the child's self-concept, as much attention as possible should be given to the affective dimension of 
teacher education programs as well as of teacher candidates. Relationship Between Teacher Behavior and Student

Achievement

Research by cantrell et al. (1977) indicated that it is possible to link teacher knowledge of behavioral principles and teacher attitude profiles to indices of both teacher classroom process and differential student achievement. First-grade teachers characterized by high knowledge of behavioral principles on the Alternative Classroom Strategies Inventory $(N=26)$ were more verbally positive with their classes and produced significantly higher residual achievement gain results for low-IQ (IQ range 50-89) and middle-IQ (IQ range 90-104) pupils than did first-grade teachers characterized by low knowledge of behavioral principles and either traditional authoritarian $(N=9)$ or traditional nonauthoritarian $(N=6)$ attitude profiles. They showed that the effective teacher of low and middle IQ first-grade pupils is: a) more knowledgeable from a behavior theory standpoint than one likely to espouse primitive, controlling strategies for dealing with pupils; b) much more positive, supportive, and comfortable with pupils than authoritarian; and c) more likely to use a higher rate of praise, of encouragement statements, and to ask more questions while still being moderately directive in the classroom. 
Relationship Between Teacher Behavior and Teacher Self-Concept and Teacher Acceptance of others

Combs et al. (1974) noted, "the individual's self is the center of his world, the point for all behavior" ( $p$. 17). According to schultz (1986), Alfred Adler (1964) was among the first to observe that there is a relationship between feelings toward the self and feelings toward others. Adler contended that "a tendency to disparage" arises out of feelings of inferiority as an overcompensation. Glasser (1969) stated that those who are convinced of their own poor self-worth tend to perceive others in negative terms. They find difficulty in cooperating with others or in forming intimate relationships--the type apparentiy necessary to promote student achievement. It is just such interpersonal relationships which stavsky (1957) defined in the quote found at the beginning of this chapter. Relationship Between Teacher Self-Concept and student Self-Concept

"The child is not born with an established self-concept. The 'self' emerges through the child's interaction with the world around him, and, in particular, through his relationships with significant people in his Iife" (Mead, 1934, p. 34). Darrigrand and Gum (1973) reported on Trickett's research, which indicated that changes in self-concept are possible as late as age ten. 
Coopersmith and Silverman (1969) found, in an intensive study of 1,748 normal, middle-class boys and their families, that parental attitude (which was related to parent self-concept) was the key factor in the development of high self-concept in their children. The boys with self-confidence and an optimistic outlook on life came from families in which the parents a) took a genuine interest in their children--their activities, friends, and interests; b) set high standards of behavior and were strict and consistent in the enforcement of rules, but used rewards rather than corporal punishment as a disciplinary technique; and c) allowed their children to have a voice in making family plans and were open to their children's suggestions (Coopersmith and Silverman, 1969). Their study has implications for educators, as significant others in the life of the child. If their findings are accurate, then an understanding of the child's perception of self and how this relates to significant others in his life is essential knowledge for educational planning and particularly teaching training.

Next to parents, teachers probably have the most pervasive effect on children's self-concepts, especially on their beliefs about their own academic abilities (Combs et al., 1974). As Kash, Borich, and Fenton (1976) explained, "Regardless of the state of self-esteem with which each pupil enters the school system, it is possible 
for the teacher as a significant or salient other and for the environment of the school to provide psychological experiences from which the pupil can derive a sense of positive self-esteem" (p. 32).

A study by Curtis and Altman (1970) explored the relationship between the teacher's perception of self and the student's perception of self. Significant differences were found between the self-concept of students in classes having teachers with high self-concept and classes where the teachers had low self-concept. Curtis and Altman found that teachers who rated themselves high on self-concept, evaluated their respective students highly, and the students' perceived view of their teachers' evaluation of them was accurate. In addition, they found that teachers with high self-concept tended to have students with high self-concepts. Relationship Between Teacher Self-Concept and student

\section{Achievement}

Since studies by coleman et al. (1966), combs et al. (1974), and Campbell (1967) have shown a correlation between student self-concept and student achievement. As reviewed in the previous section, one might expect that teachers with high self-concept would have classes with higher student achievement.

The research of Aspy and Buhler (1975) is consistent with this hypothesis. Their study investigated the 
relationship between teachers' levels of Inferred Self-Concept and the cognitive growth of their students. In their study 120 third grade students were matched for sex and I.Q., and their cognitive growth was determined by pre- and posttesting of the stanford Āchievement Test. The levels of inferred self-concept for the six selected teachers were determined by three raters who completed the Parker's self-Concept Checklist after observing each teacher for one hour. The levels of Inferred self-concept were related positively to the students' cognitive growth at the .01 level of significance.

Relationship Between Teacher Acceptance of others and Student Self-Concept

Quandt (1973) stated that the cornerstone of previously described techniques to improve student seif-concept is a nonjudgmental, accepting attitude by teachers. He emphasized the necessity for rejecting undesirable behavior while at the same time accepting the child.

An investigation by Davidson and Lang (1960) sought to determine the relationship between children's perception of their teachers' feelings toward them and the variables of self-perception, academic achievement and classroom behavior. The subjects of their study were 89 boys and 114 girls, attending 4th, 5th, and 6th grades of a New York city public school. These children were distributed 
in 10 different classrooms. In terms of reading ability, the classes selected were in the upper half of their respective grade level. The children represented a wide range in socio-economic status and were grouped into three distinct groups on the basis of their fathers' and mothers' occupation. The upper group, consisting of 63 children, came from families of professional people, white collar workers and business men; the middle social class group of 57 children had parents who were skilled workers; the low group contained 83 children of semi-skilled and unskilled workers and a number of unemployed.

A Checklist of Trait Names was administered twice to the children. At the first administration, the children were instructed to respond to the 35 adjectives comprising the list in terms of "My teacher thinks I am," and at the second testing, in terms of "I think I am." "MY teacher thinks I am" scale yielded a measure of perceived teacher feelings and the "I think I am" scale yielded a measure of self-perception.

The teachers, nine women and one man, rated their pupils on academic achievement, on a four-point scale: "Very Well, Adequately, Below Average, and Very Poorly." Davidson and Lang's findings indicated: 1) The children's perception of their teachers' feelings toward them correlated positively and significantly with their own self-perception. The child with the more favorable 
self-image was the one who more likely than not perceived his teachers' feelings toward him more favorably. 2) The more positive the children's perception of their teachers' feelings, the better was the children's academic achievement and the more desirable was their classroom behavior as rated by the teachers. 3) children in the upper and middle social class groups perceived their teachers' feelings toward them more favorably than did the chilaren in the lower social class group. 4) Social class position was also found to be positively related with achievement in school. 5) Girls generally perceived their teachers' feelings more favorably than did the boys. 6) Finally, there were some significant classroom differences in the favorability of the children's perception of their teachers' feelings.

Davidson ard Lang (1950) concluded, "It seems urgent that teachers be helped to recognize the significance of the feelings which they express toward children, consciously or unconsciously. Some teachers, in addition, may need the help which can only come through a process of self-understanding, in order to avoid or to minimize the expression of negatively-toned feelings toward children, because of their sex, their socio-economic status, their behavior or achievement in school" (p. 114).

Teachers who are accepting of others seem to have a more positive view of others. They are not prone to view 
others as critical, attacking people with ulterior motives, but rather see them as friendly and worthwhile in their own right. They have the ability to see things from the other person's point of view. These teachers have been shown to have a more favorable view of democratic classroom procedures (Cheong \& Wadden, 1978). In other words, they do not see students as persons "you do things to," but rather as individuals capable of doing for themseives once they feel trusted, respected, valued. Relationship Between Teacher Acceptance of others and Student Achievement

The studies of Reed and Goetz (1980) demonstrated a connection between teacher positive attention and student achievement. They cited Miller (1976) and Samuels (1977) as indicating that teacher attention to each child in preschool programs is important for it conveys social acceptance to a child, which in turn helps develop the child's self-concept. In support of their study, they quoted Vygotsky (1962) as finding that positive dialogue between adult and child is a critical factor influencing language development and cognitive growth. Thus, Reed and Goetz (1980) concluded lack of teacher attention might hinder a young child's development of a positive self-concept, language and cognitive growth. 
Relationship Between Teacher Self-Concept and Acceptance

\section{of others}

Berger (1952) based his study on the findings of Sheerer (1949) who found, in her study, a definite and substantial correlation between attitudes of acceptance and respect for the self and attitudes of acceptance and respect for others. Her study, based on a small number of counseling cases, showed that perceptions of others, feelings toward others, and acceptance of others are significantly related to the perception of self, feelings about self, and acceptance of self. However, it appeared to Berger that there was a need to test this relationship with larger numbers of cases and more varied samples than had thus far been studied. He determined, therefore, to I) develop a group instrument for the measurement of self-acceptance and the acceptance of others, and 2) test the relationship between these variables in a variety of groups, using the developed instruments. Berger conciuded that evidence for a positive correlation between acceptance of self and acceptance of others was definitely supported and strengthened by the results of his study.

Fey (1955) also researched the relationship between teacher self-concept and acceptance of others. Specifically, it was found that while expressed attitudes of self-acceptance and of acceptance of others tend to 
vary together, there are persons who are exceptions to this rule. They appear to reveal something of the way they defend themselves interpersonally. Individuals showing low self acceptance and high acceptance of others appeared to be "intropunitive self disparagers" those with high self acceptance and low acceptance of others appeared to be "extrapunitive projectors." With respect to Fey's study and the work done by cantrell et al. (1977), it follows that teachers who have high self-concept and low acceptance of others might be more authoritarian in their classroom behavior, and thus have students with lower achievement scores.

Omwake (1954) designed a study to test the assumption that, in a normal population, there is a positive correlation between the acceptance of self (good self-concept) and the acceptance of others. To test the hypothesis, he used three unpublished tests measuring attitudes toward the self and toward others which were administered to 113 college students who took them anonymously. The tests were: the scale for Self-Acceptance and Acceptance of Others, the questionnaire on Attitudes Toward the self and others, and the Index of Adjustment and Values for self and for others. The three measures of self-acceptance agreed closely; those for attitudes toward others agreed less well. The results support the contention that there is a 
marked relation between the way an individual sees himself and the way he sees others; those who accept themselves tend to be acceptant of others; those who reject themselves hold a correspondingly low opinion of others. Driscoll and Reynolds (1980) conducted a study in which they identified characteristics which teachers used to describe the students toward whom they had positive attitudes, and then examined the extent to which teachers' perceptions of themselves (self-concept) were mirrored in their descriptions of students whom they held positive attitudes. In order to conduct the experiment, they first examined physical characteristics of students, who were targets of teachers' positive attitudes; then, they examined personality characteristics of those students who were targets of teachers' positive attitudes; third, they assessed teachers' perceptions of their own physical and personality characteristics. Lastly, they examined the relationship between teachers' self-perceptions and their descriptions of students toward whom they held positive attitudes. Results of the data analysis indicated: teachers use a common set of characteristics to describe themselves and a parallel set of characteristics to describe students for whom they hold positive attitudes. There were significant correlations between teacher self-descriptions and descriptions of favored students, "suggesting trends in the formation of teacher 
attitudes." For instance, teacher "first impression" data might be accurate and be reinforced by later experience with students. An alternate explanation could be that "first impressions" influence teacher attitudes, which then affect teacher interactions, which in turn alter student response to teachers, eventually modifying students to approximate "first impressions."

of equal consideration are the relationships between teachers' self-perception and their description of that group of students for whom they hold positive attitudes and expectations. The process of development of teacher attitudes and expectations may include student physical and personality traits and the relationship between those traits and those which teachers perceive themselves possessing.

\section{Suminary}

In summary, the results of numerous studies strongly suggest that there should be a correlation between teacher self-concept/acceptance of others and student achievement. Campbell (1967), Combs et al. (1965), Franks and Dillon (1976), and Coleman (1966) concluded that there is a positive relationship between student self-esteem and student achievement. The studies of Franks and Dillon (1976) and Cheong and Wadden (1978) lead to the conclusion that there is a positive correlation between teacher 
behavior and student self-concept. Cantrell et al. (1977) found a positive relationship between teacher behavior and student achievement. The findings of combs et al. (1976) and Glasser (1969) suggested there shoula be a relationship between teacher behavior and teacher self-concept/acceptance of others. Studies by coopersmith and Silverman (1969) and combs et al. (1974) and by Kash et al. (1976) indicated that there is a positive correlation between teacher self-concept and student self-concept. Only the published study of Aspy and Buhler (1975) directly approached the problem of detecting a positive relationship between teacher self-concept and student achievement, but, unlike the present investigation, it examined two variables (teacher inferred self-concept and student achievement). The current study included a third variable, teacher acceptance of others. 
CHAPTER III

\section{Research Design/Methodology}

You see, really and truly, ....the difference between a lady and a flower girl is not how she behaves, but how she's treated. I shall always be a flower girl to Frofessor Higgins, because he treats me as a flower girl, and always will; but I know I can be a lady to you, because you always treat me as a lady and alvays will.

Eliza Doolittle to Colonel Pickering George Bernard Shaw, Pygmalion

Just as Eliza Doolittle developed into a lady because Colonel Pickering treated her as a lady, studies such as Franks and Dillon (1976) and Davidson and Lang (1960) have indicated that a teacher's behavior and attitude can affect a child's self-concept and consequent behavior/achievement. This study was designed to test the hypothesis that there is a relationship between teacher self-concept, teacher acceptance of others (which, according to literature is manifested in teacher behavior) and student achievement.

\section{Hypotheses--in null form}

1. Student achievement is not related to teacher self-concept.

2. Teachers' acceptance of others is not positively related to student achievement.

3. There is not a higher correlation between teacher acceptance of others and student achievement than between teacher self-concept and student achievement. 


\section{Research Design}

Two groups were involved in the sampling procedure, 198.8-89 fourth grade teachers and 1988-89 fourth grade students. Teachers were asked to volunteer for the study. The Tennessee Self-Concept (Roid and Fitts, 1988) and the Bogardus Social Distance scale (Bogardus, 1967), which measured acceptance of others, were given to teachers. In addition, teachers were asked to answer a Teacher Questionnaire which included questions concerning the teachers' travel, number of hours taken beyond the bachelor's degree, major field of study, and number of years of teaching experience (see Appendix A).

All 1988-89 AY students of the participating teachers were selected for the study. The Iowa Test of Basic Skills, which had been previously administered by the participating teachers during the Spring of 1988-89, was used to assess the class mean National Percentile Achievement Rank. Research Universe and Sampling Procedures

Total student Population

The student sample consisted of 775 fourth-grade students from 15 public schools. The student population, which was over $12 \%$ minority (black, Hispanic, Aleutian and American Indian), consisted of 387 males and 388 females. There was a $7 \%$ dropout rate in 1988-89 within the school district. This represented students who dropped out of high school for reasons other than moving or health. 
Seven and two-tenths percent of the families of the

population city were below the poverty line according to the 1980 census.

\section{Teacher Population}

The teacher population who volunteered for the study consisted of 31 out of a total of 37 1988-89 fourth grade teachers of the selected school district. These teachers came from 15 different public schools. Of the 4 males and 27 females who participated in the study, all were caucasian except one Asian female. Twenty-nine of the 31 teacher participants responded to the Teacher Questionnaire. (See Table 1 for the results).

The data collected from this questionnaire indicated: the teaching experience of the teachers ranged from 3 to 42 years; approximately $54 \%$ of the teachers were middle-aged and had more than 20 years of experience, and only 3 of the 31 teachers had less than 10 years of experience. All of the teachers had taken at least 10 units beyond their bachelor's, and over half had completed 30 units or more. The majority of the teachers majored in Elementary Education $(62 \%)$. The remaining teachers majored in: Educational Administration (1), General Education (2), English (1), History (2), Science (1), and German (1). Travel among approximately $55 \%$ of the teachers had not been extensive-- 


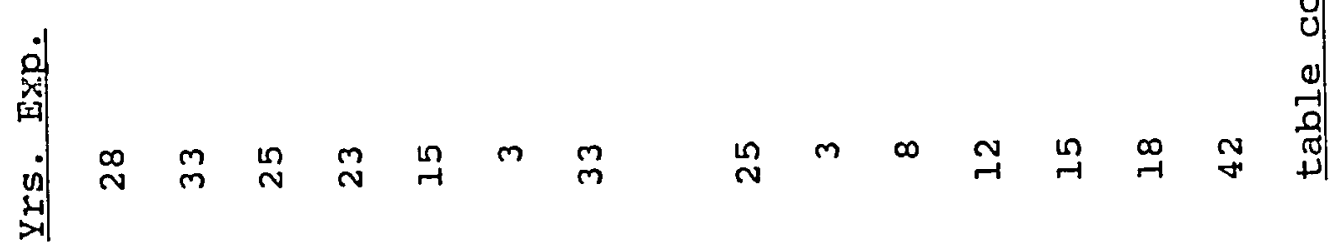

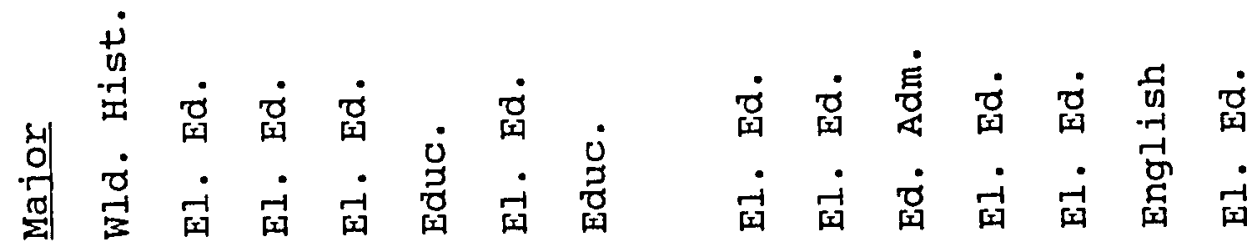

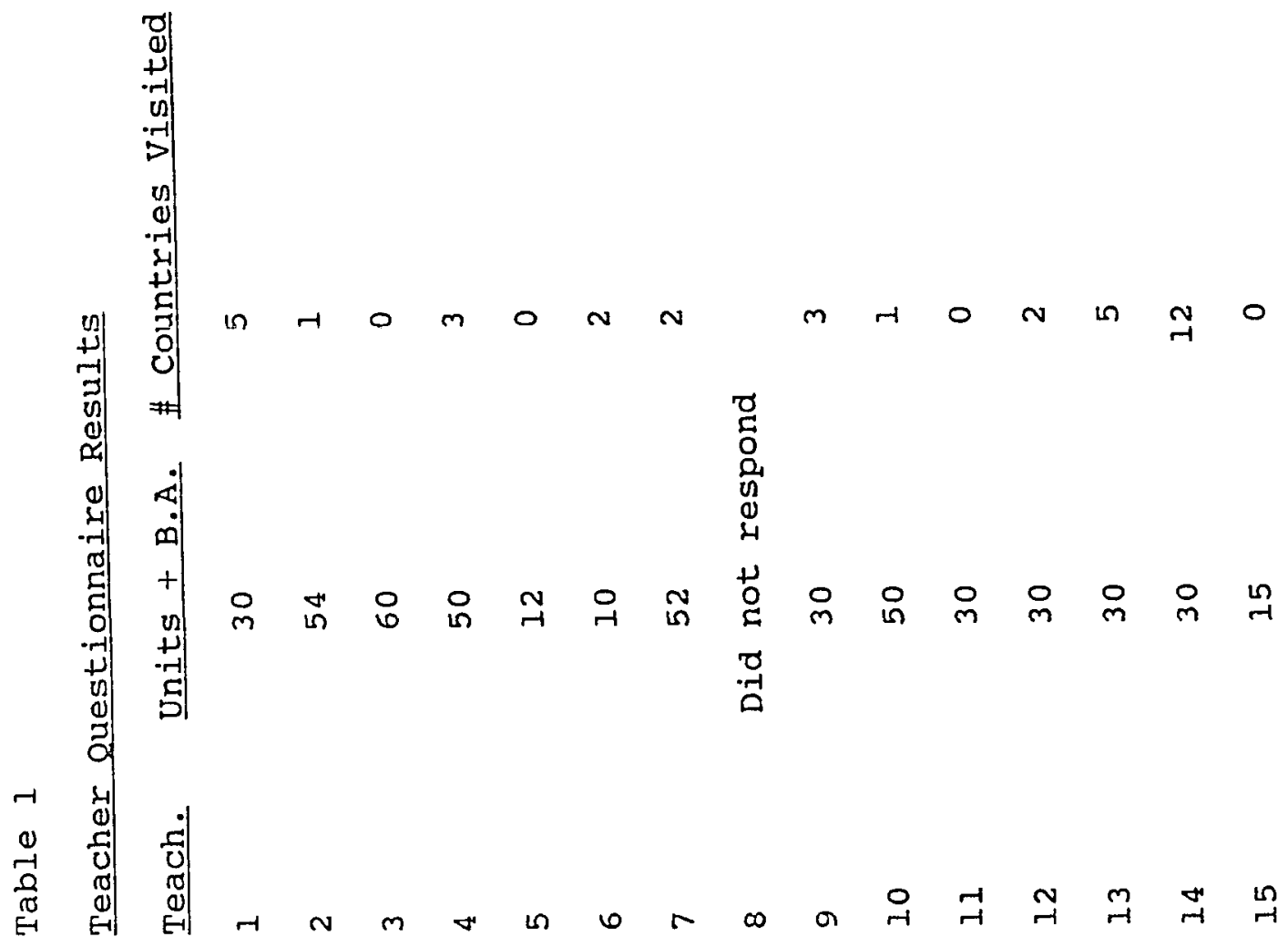




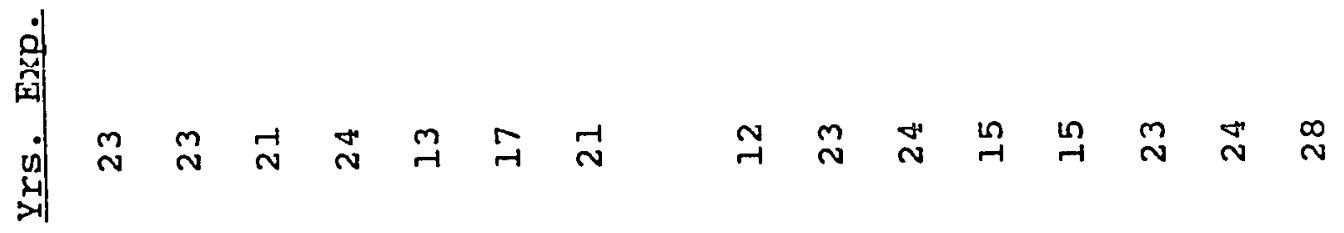

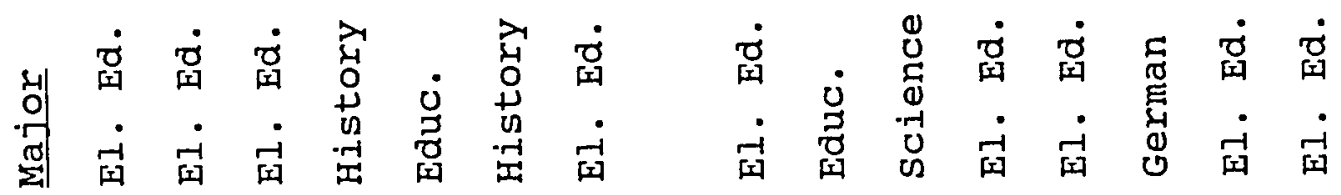

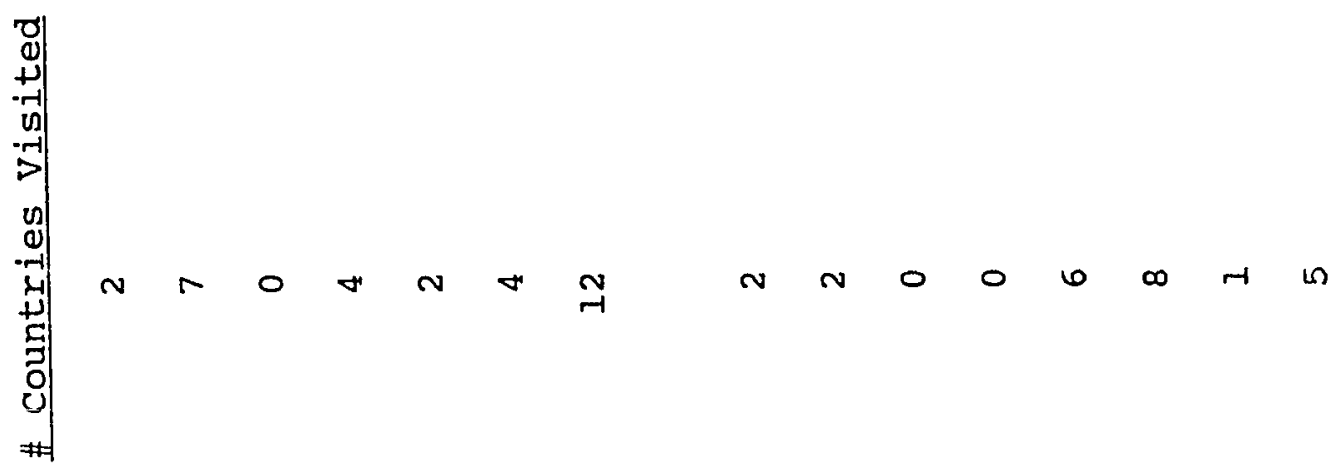

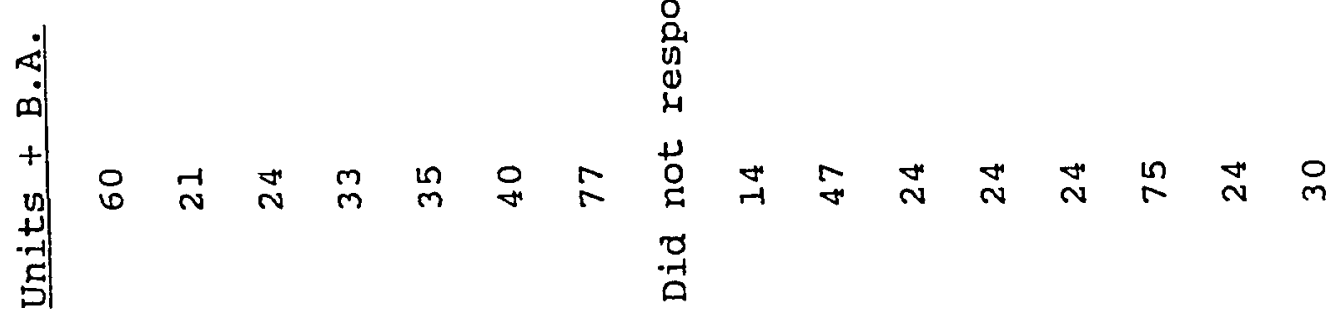

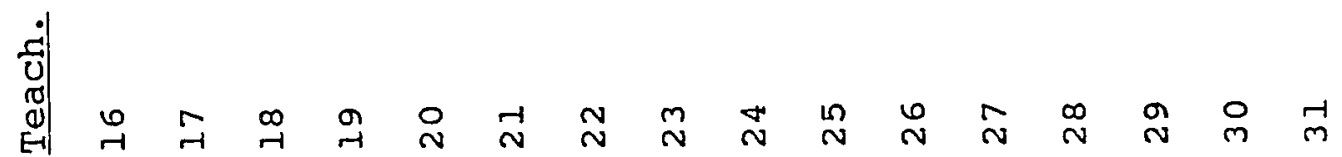


7 (almost one-fourth) had not been out of the United States, three had visited one country, and 7 had visited 2 countries, i.e., Mexico and Canada. The remaining $46 \%$ had traveled to anywhere from 3 to 12 countries. Travel was included in the questionnaire since it could conceivably contribute to a teacher's understanding and appreciation of different cultures.

Salient Characteristics of both the Universe and the Sample

since the teacher selection and thus the student selection were almost universal for the community, it was assumed that the sample was representative of the total population of that community.

Specification of the sufficiency of the sample selected

1. The author determined the sample size based on the number of students that comprised the classrooms of 31 teachers. The school district sent the researcher an anonymous listing of all the students per class. The listing designated the classroom teacher, the ethnicity of each student, and the students qualifying for free or reduced-price lunches.

2. The teachers were ranked with respect to their scores on the Tennessee Self-Concept Scale (TSCS), the Bogardus Social Distance Scale, and the National Percentile Rank (NATP) of their class on the Iowa Test of Basic Skills (ITBS) (see Table 2). A Spearman Rank order correlation Coefficient was then used for the statistical analysis. 


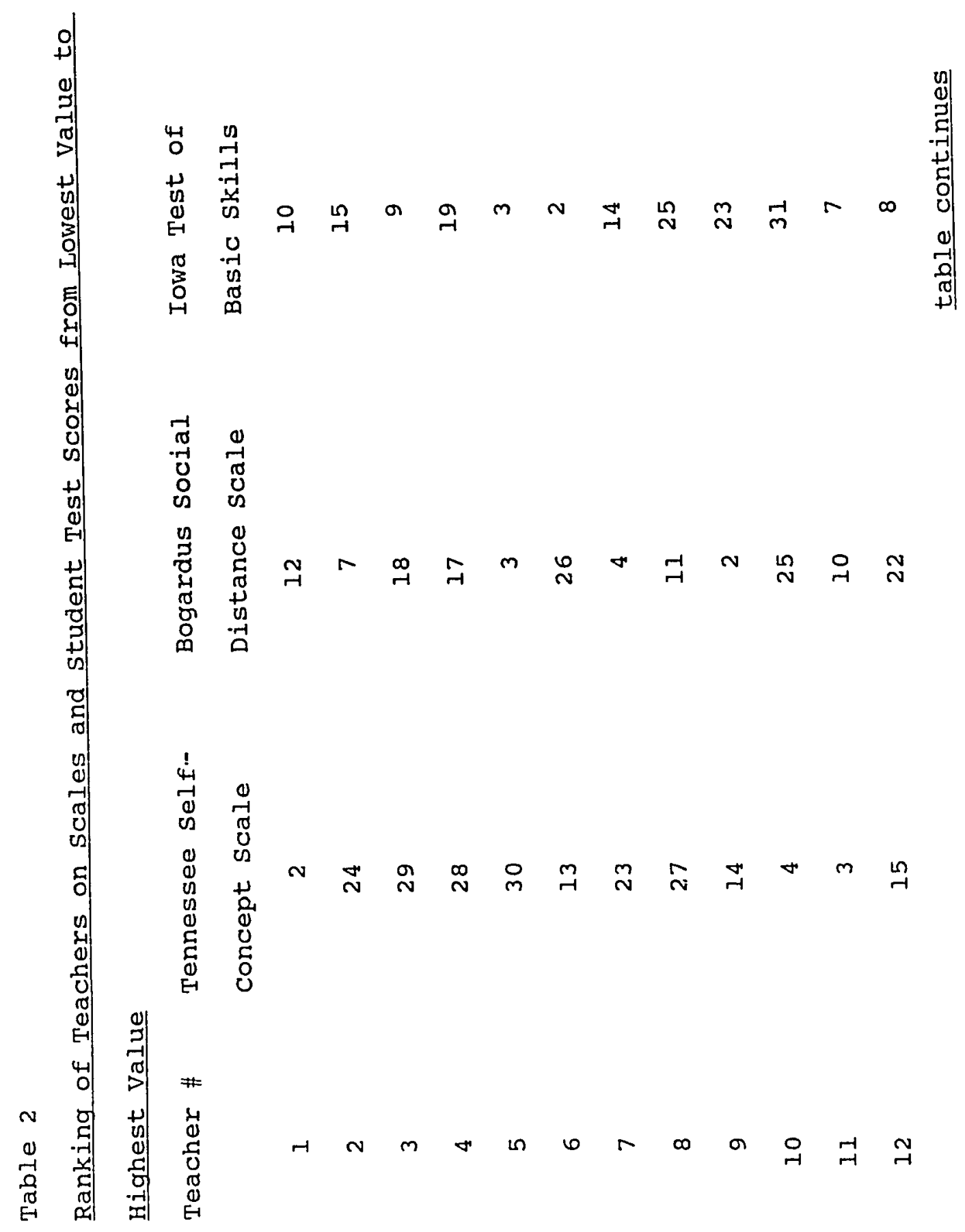




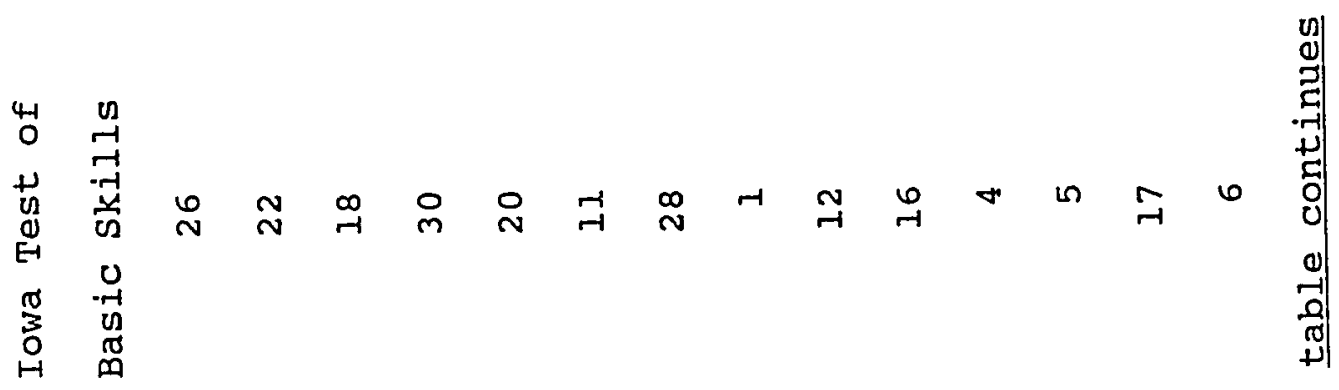

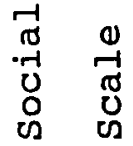

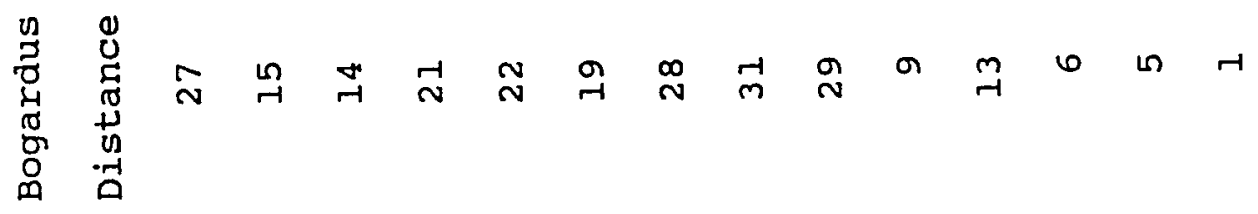

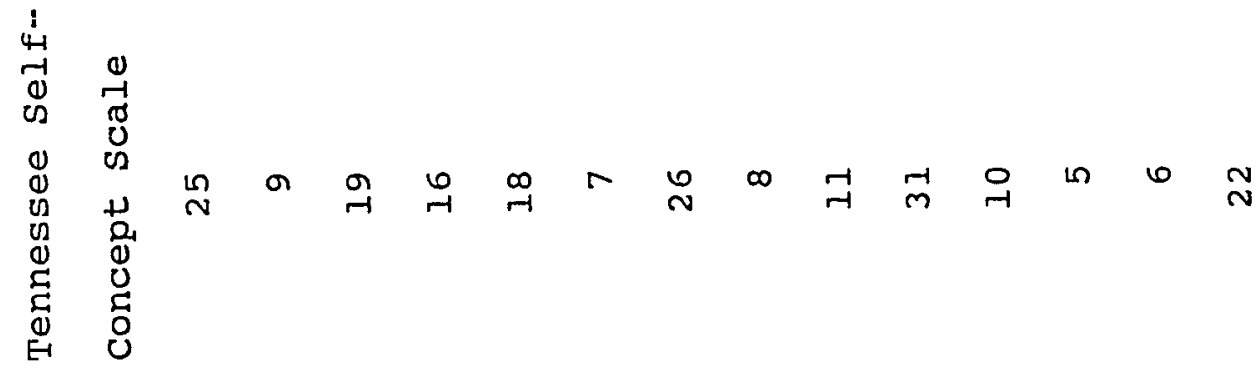

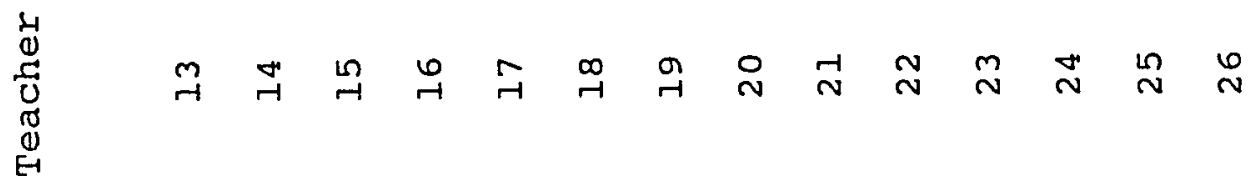



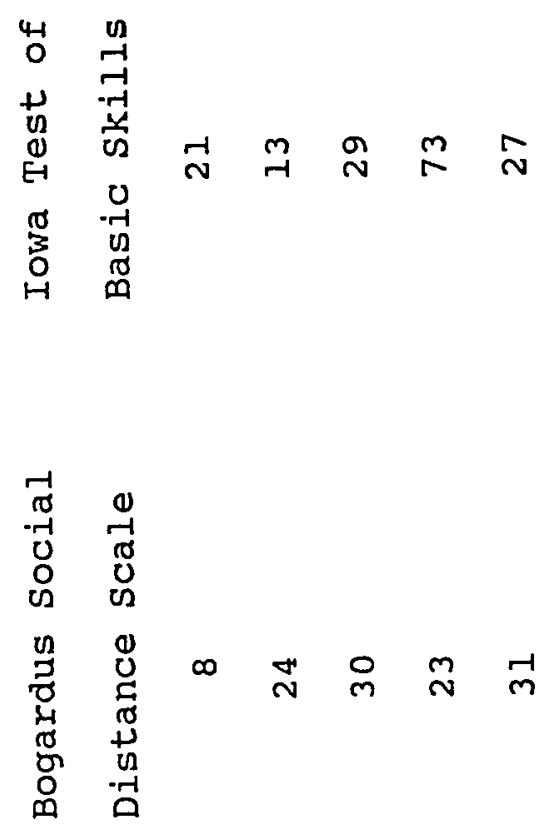

$\begin{array}{lll}n & 0 & \text { in } \\ 0 & n & \text { in }\end{array}$
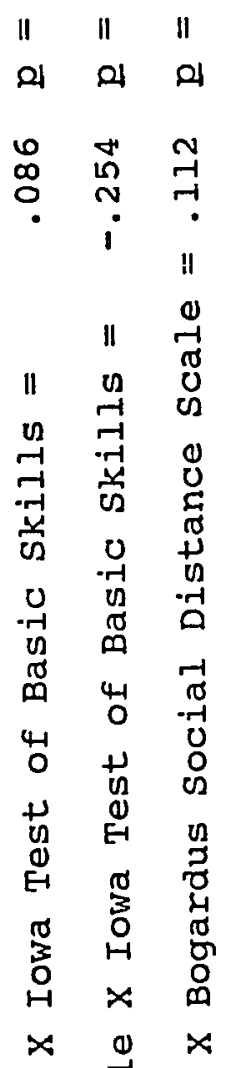

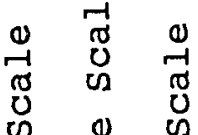

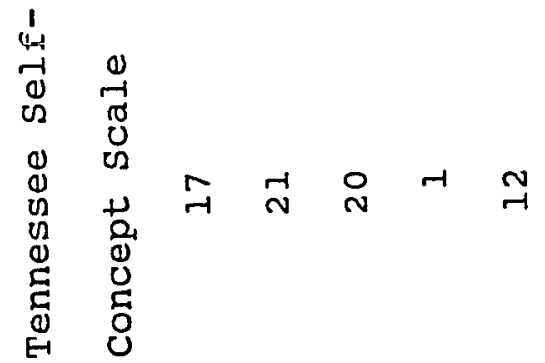

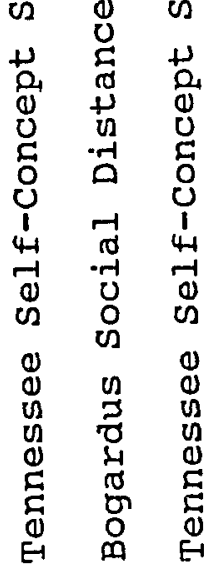

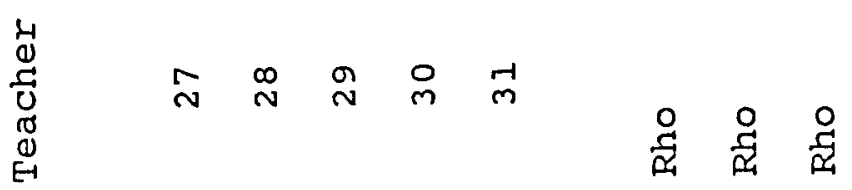




\section{Data-Gathering Tools/Instrumentation}

Tools Used to Collect Relevant Data

1. Student demographics as provided by the school

district

2. Iowa Test of Basic Skilis

3. Tennessee Self-Concept Scale (See Appendix B)

4. Bogardus Social Distance Scale (See Appendix C) Brief synopsis of the Tools

1. Student demographic information was provided by the school district and revealed the ethnicity and socio-economic status of the students' families.

2. The Iowa Test of Basic Skills (ITBS) was used to determine class achievement. The test included subtests on vocabulary, reading, language skills, work-study skills, and mathematics skills. It is a widely used, standardized test in which the validity and reliability have been examined in detail. The tests included a National Curve Equivalent for each student, a National Grade Equivalent for each student, and a class mean National Percentile Rank. This study used the mean National Percentile Rank of the composite Achievement score for each class.

3. Tennessee self-Concept scale, which was used to measure teacher self-concept, was developed by William H. Fitts in 1965. It is a self report questionnaire consisting of 100 self-ãescriptive statements. The reliability estimate on the total score was .90 based on 
test-retest with 60 college students over a two-week period. A number of studies have provided evidence of the reliability of the TSCS scores. For example, using a shortened version of the TSCs with psychiatry patients, Congdon (1958) obtained a reliability coefficient of .88 for the Total score. Nunnelly (1968) reported a split-half reliability of .91 for the Total score on the TSCS. More recently, stanwyck and Garrison (1982) reported an internal consistency estimate of .92 for the Total score and .66 for self-Criticism, based on a dichotomization of items. In addition, stanwyck and Garrison conducted a Rasch analysis (Rasch, 1980), and found that 82 of the 90 Total score items (with dichotomization into True/False categories) met

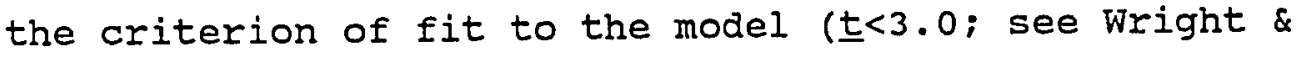
stone, 1979). Thus, the responses to TSCS items showed an approximate consistency in the shape of their item characteristic curves in relation to a theoretical trait of general self-concept. It required about 20 minutes for a teacher to fill out.

4. The Bogardus Social Distance Scale was the instrument employed to determine the teachers' acceptance of others. It was designed to be used in a forty year racial distance study by Emory $s$. Bogardus. The study was conducted in four different years, namely, in 1926, 1946, 1956, and 1966. The instrument has been subjected to validity and reliability checks. Bogardus (1967) cites 
E.W. du Vall (1950) as finding the Racial Distance Scale to be internally consistent. The study by du vall also showed that the scale had validity. Hartley and Hartley (1952) stated that the original Bogardus scale has proved highly reliable as a measure of general social distance. In testing the scale's reliability, they reported that split half reliability coefficients of .90 and higher have repeatedly been obtained, and that it has been the most widely used instrument of its kind and has yielded illuminating results. Sherif and sherif (1956) concluded that when using the Bogardus Social Distance Scale and variations of $i t$, the social distance at which one group places others is indicated satisfactorily. They added that on the whole, the Social Distance scale has been one of the most useful devices for tapping attitudes of one group toward another. Bogardus (1967) stated that in a specially devised test of the Bogardus Social Distance Scale, Sartain and Bell (1950) found that the scale made a creditable reliability showing. Provisions for Validity and Reliability

1. All the tests were standardized.

2. Identical instructions were read to the teachers in the administration of the Tennessee self-Concept Scale and the Bogardus Social Distance Scale.

3. The same achievement tests were used for all the students. They had been administered the previous academic 
year by the participating teachers.

4. Teachers were given a list of definitions to aid them in answering the Political and Economic subtest of the Bogardus Social Distance Scale because some of the terms were not commonly understood. This should have added to the consistency and reliability of the answers. (See Appendix D)

\section{Procedures for Collection of the Data}

Application of the Data-Gathering Tools to the Sample Population

1. A listing of all fourth grade teachers and their respective schools was obtained from the superintendent of the population school district along with his approval to involve the teachers in the study, pending their voluntary cooperation.

2. A Human Subjects Protocol was submitted to San Jose State University for approval. (See Appendix E)

3. The district office informed the principals of the impending research project.

4. A cover letter, explaining the research project and requesting voluntary participation in the project, was mailed to all 88-89 fourth grade teachers of the selected school district. (See Appendix F)

5. Principals of the respective schools were contacted by the researcher in order to arrange meetings between the researcher and the teachers. 
6. The researcher had meetings for participating fourth-grade teachers at their respective buildings in order to administer the Tennessee self-Concept Scale, the Bogardus Social Distance Scale, and the Teacher Questionnaire. Each teacher was asked to read and sign the Consent Form (see Appendix G) prior to taking the tests and filling out the questionnaire. The researcher gave the teachers identical instructions (see Appendix H) for filling out the scales; the teachers were requested not to discuss the tests with anyone until all forms had been collected. The teachers were also reassured of the confidentiality of their answers. (Instructions required about 10 minutes of teacher time.) The researcher stayed with the teachers until the scales had been completed, and they were collected at that time.

7. Spring, 1988-89 student achievement test scores were collected from the district office and recorded into the database.

8. Results from the Tennessee Self-Concept scale and the Bogardus Social Distance scale were recorded into the database. Information from the Teacher Questionnaire was also taken into consideration in the analysis. Provisions for Assuring Uniformity/Reliability in the Collection of the Data

1. The author set the date and was present on the days the teachers were administered the tests. This was to 
assure uniformity in the instructions, appropriate timing of the tests, and to guarantee that there would be no inappropriate communication between the participants.

2. The author collected the test results from participating teachers at the culmination of the tests.

3. The same level and the same type of achievement test was used in evaluating the performance of all students.

4. Student achievement tests were administered at approximately the same date.

Provisions for codifying the Mailed Instruments and Follow Up

The assigned numbers of the fourth grade teachers, as well as their respective schools, were typed on the heading of all the class lists of the ITBS results. The author kept a listing of the teachers, their respective schools and their corresponding assigned number in order to identify the two scales and the corresponding classes of the students. The Tennessee Self Concept Scale (TSCS) and the Bogardus Social Distance Scale were identified only by this number; the same was true for any statistical analysis. A follow-up letter was sent to the Director of Personnel and the principals of the participating school district, thanking them for their willingness to participate in the study. 


\section{Procedures for Analysis of the Data}

The hypotheses were tested using the following

dependent variables.

1. The teacher sample included teacher self-concept and acceptance of others.

2. The student sample included student achievement test scores. Explanation of the Statistical Devices Used on the Data, and Their Suitability for the Purpose Intended

1. The researcher ranked the mean National Percentile Rank (NATP) score for the achievement tests of each class, from lowest to highest.

2. Each teacher's total percent score for self-concept on the TSCS was ranked from lowest to highest and correlated to the class mean NATP.

3. The researcher computed the mean score of the teachers for each of the subgrouping of the Bogardus scale, i.e., ethnic distance, occupational distance and political and economic distance and total social distance. She ranked the mean scores from lowest to highest, and then determined the correlation between teachers' acceptance of others and class NATP mean achievement score. 4. The researcher used the above data to test the hypotheses of this study. 


\section{CHAPTER IV}

\section{Results}

In conjunction with the three hypotineses set forth in this study, the research questions were as follows:

Question \#I: What is the relationship between teachers' self-concept and student achievement?

In order to examine the relationship between teachers' self-concept and student achievement, the thirty-one teachers were administered the Tennessee Self-Concept Scale (TSCS). This test allowed the teachers to describe their ideas and feelings about themselves, their abilities and their day-to-day actions. It was not a test, in the sense of having right or wrong answers, so there was no concern about getting a high score. Instead, the scale was designed to give the person taking it a chance to compare several parts of the scale in order to find areas of relative strength or areas that they felt might need attention.

First, the test provided a score "profile" (see Figure 2). This showed the scores based on different parts of the questionnaire. The Total score is the single most important score on the TSCS. It reflects the overall level of self-esteem. An individual with a high Total score tends to like himself or herself, feels that he or she is a person of value and worth, has self-confidence, and acts 


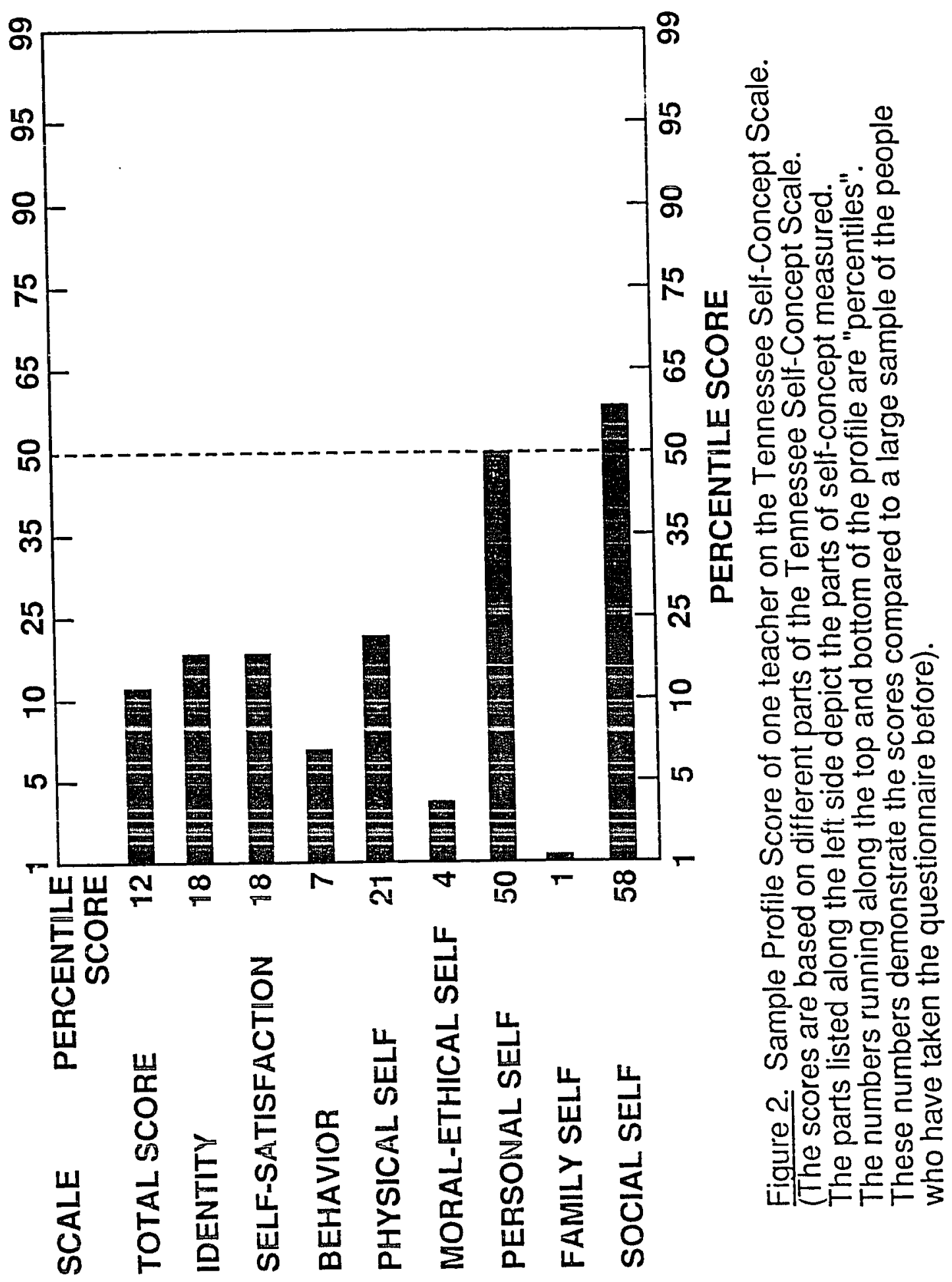


accordingly. An individual with a low Total score is doubtful about his or her own worth, sees himself or herself as undesirable, often feels anxious, depressed, and unhappy, and has little self-confidence (Roid \& Fitts, 1988). If a teacher's score was at the 50th percentile, it meant that half $(50 \%)$ of the people scored lower than that teacher did. In the present study, the percentage total scores indicating the degree of self-concept of the teachers on the TSCS ranged from $14 \%$ to $99 \%$. The average percentile score on the TSCS for the present sample of teachers was $75.85 \%$ (see Table 3 ).

The AY 1988-89 Iowa Tests of Basic Skills, which had been administered to the students by the sample teachers the previous spring, were used to determine class achievement. The class achievement scores for the 31 classes ranged from $30 \%$ to $92 \%$ on the National Percentile Ranking (NATP) of the Iowa Test of Basic Skills. A class average percentile score of $50 \%$ meant that half (50\%) of the classes taking the test at that time scored lower than that particular class. Both the mean and median score of the 31 classes was $63 \%$ (see Table 3 ).

Figure 3 plots student achievement scores against teacher self-concept test results. The spearman Rank order correlation coefficient is $.086(\underline{\underline{p}}=.655)$. This is small and does not meet the required .361 (see Table 4 ) for statistical significance (Wright \& Stone, 1979, p. 279). 


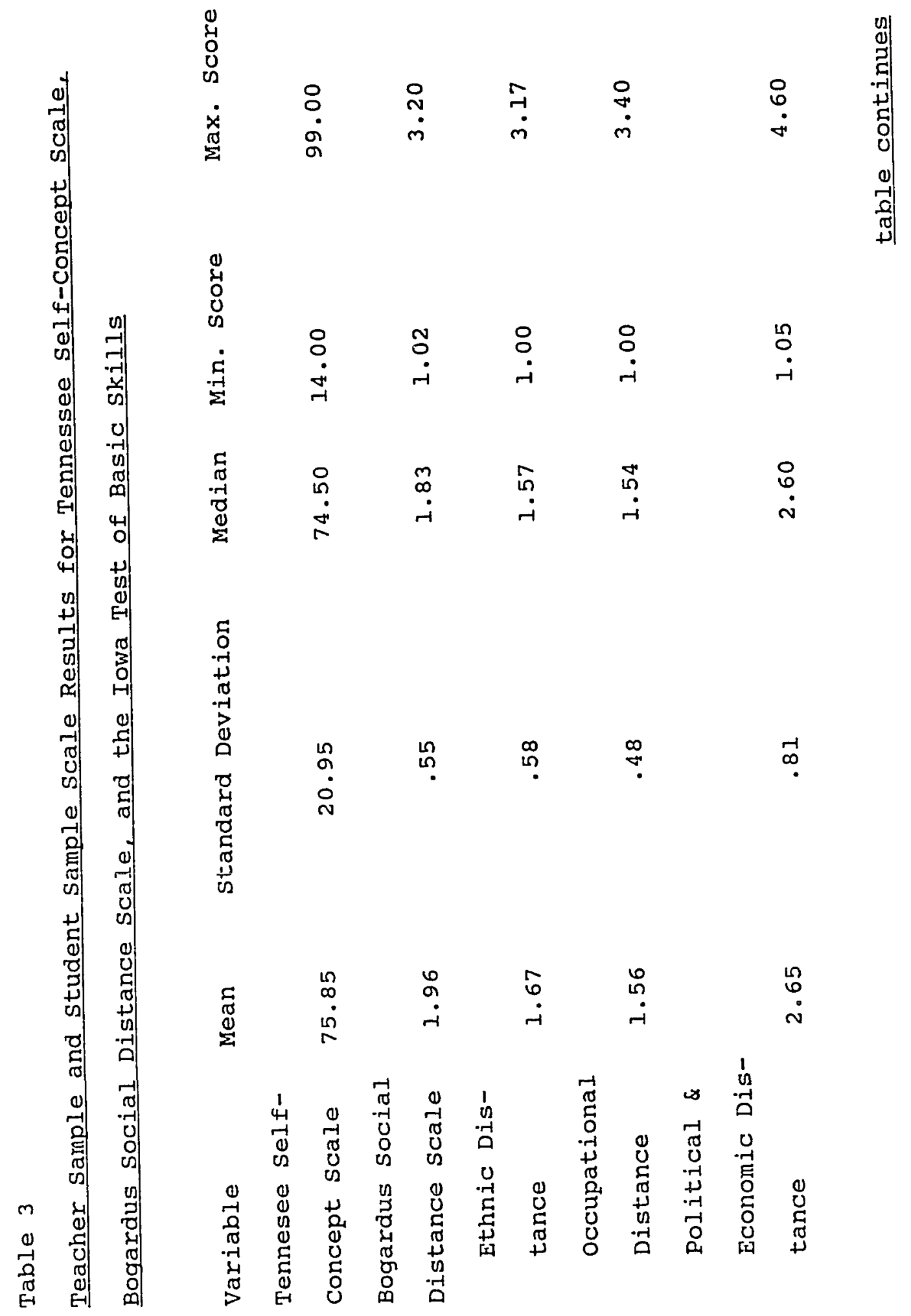




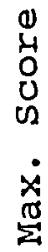

$\begin{array}{ll}\dot{x} & 0 \\ \dot{\pi} & \dot{0} \\ & \text { on }\end{array}$

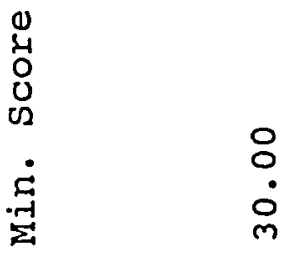

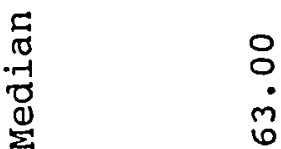
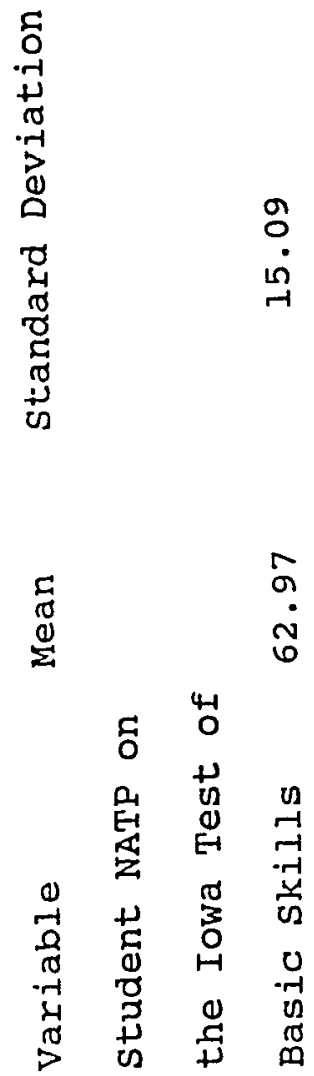


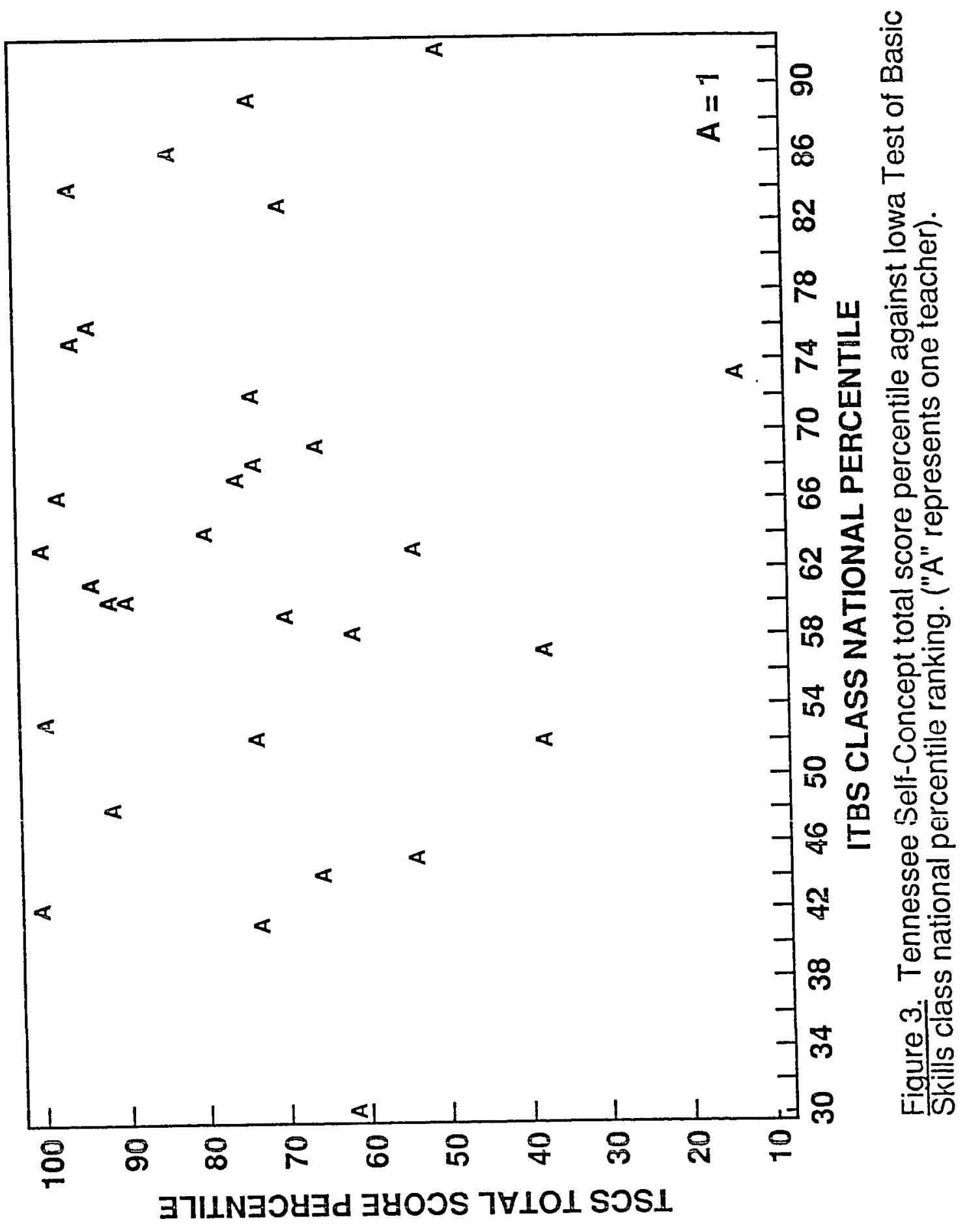




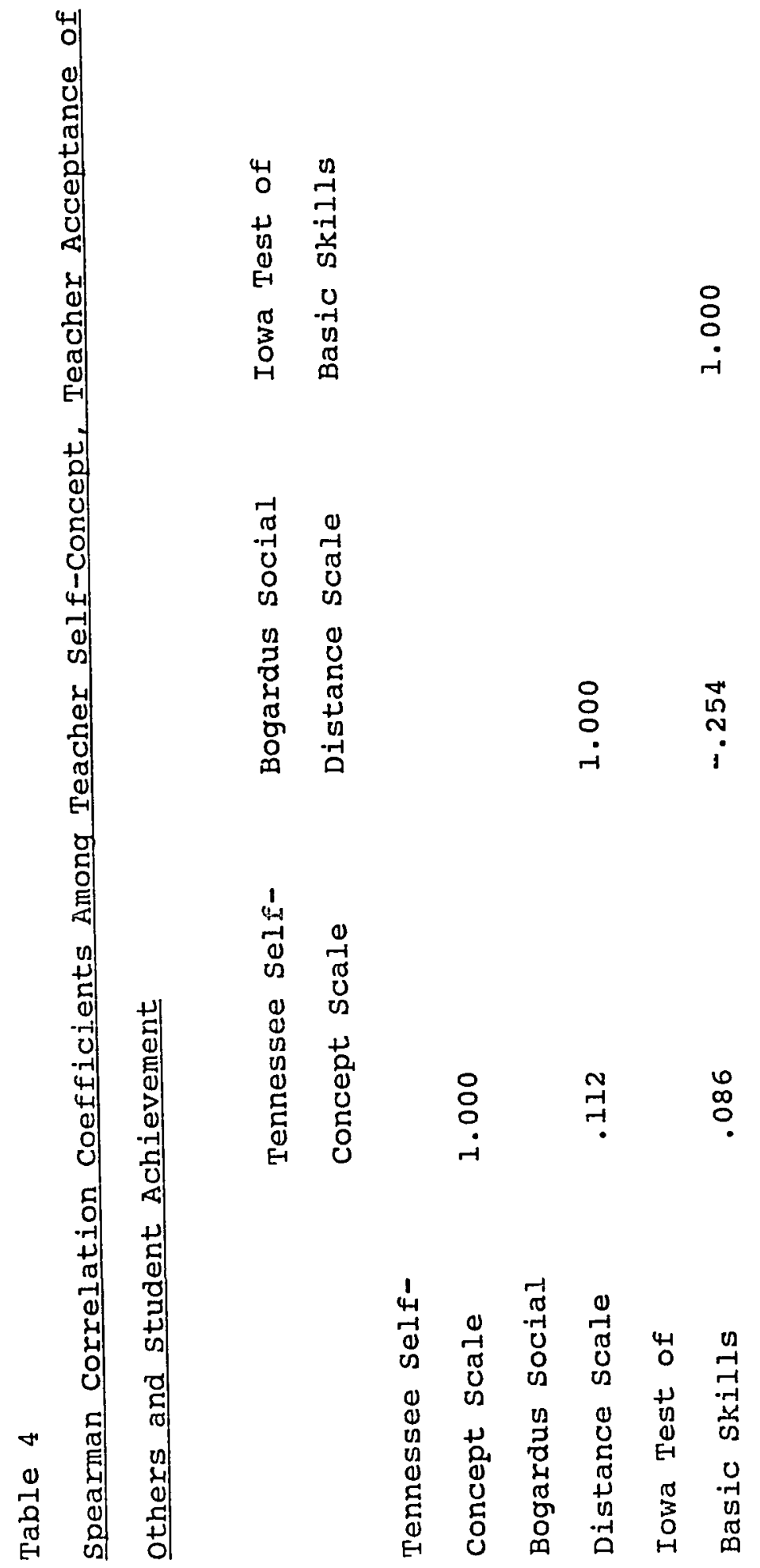


Although the correlation is in the hypothesized direction, it indicates that there is no systematic relationship between these two variables. Indeed, in Figure 3, one can see that when student achievement was plotted against teacher self-concept, no clear pattern was reflected. Question \#2: What is the relationship between teachers' acceptance of others and student achievement?

In Table 3 , it can be seen that the median total social Distance scores (Soc. Dist.), which was the indicator for "acceptance of others" for the teachers, ranged from 1.02 to 3.20 on the Bogardus Social Distance Scale. The Social Distance was a composite scale score consisting of Ethnic Distance, Occupational Distance, and Political and Economic Distance. The subscales of the Bogardus ranged as follows: 1.00 to 3.17 - Ethnic Distance (Ethn. Dist.); 1.00 to 3.40 - Occupational Distance (Occu. Dist.); 1.05 to 4.60 - Political and Economic Distance (Poli. Dist.). Theoretically, the Social Distance Index could range from 1.00 to 7.00 , but actually it rarely reaches the least possible level of 1.00 , and never the greatest possible farness degree of 7.00 , except on the part of a rare individual who has developed a stubborn antagonism for the members of some racial group. The usual range is from 1.00 to about 3.50 (Bogardus, 1967). Each of these distances was compared to the students' 
achievement in order to determine the teachers' acceptance of others. Again, the results indicated no statistical significance. The spearman Rank order correlation showed a -.254 correlation $(\underline{\underline{p}}=.176)$ between student achievement and total social distance (acceptance of others). When the relationship between acceptance of others and student achievement was plotted graphically (see Figure 4), it reflected the low correlation. As with the first hypothesis, the correlation was in the expected direction since the lower the score on the Bogardus, the higher the acceptance of others; whereas, the higher the ITBS score, the higher the achievement of the class. Although the correlation coefficient suggests a trend in the direction consistent with the hypothesis underlying the research question, it is not statistically stable.

The negative correlation $(-.254)$ is explained by the fact that the lower the score on the Bogardus scale, the more accepting is the teacher, in contrast to the higher the score on the TSCS, the better the self-concept of the teacher.

Question \#3: How do teachers' self-concept and acceptance of others compare in their influence on student achievement?

Although the correlation between teacher acceptance of others and student achievement $(-.254)$ seems higher than between teacher self-concept and student achievement 


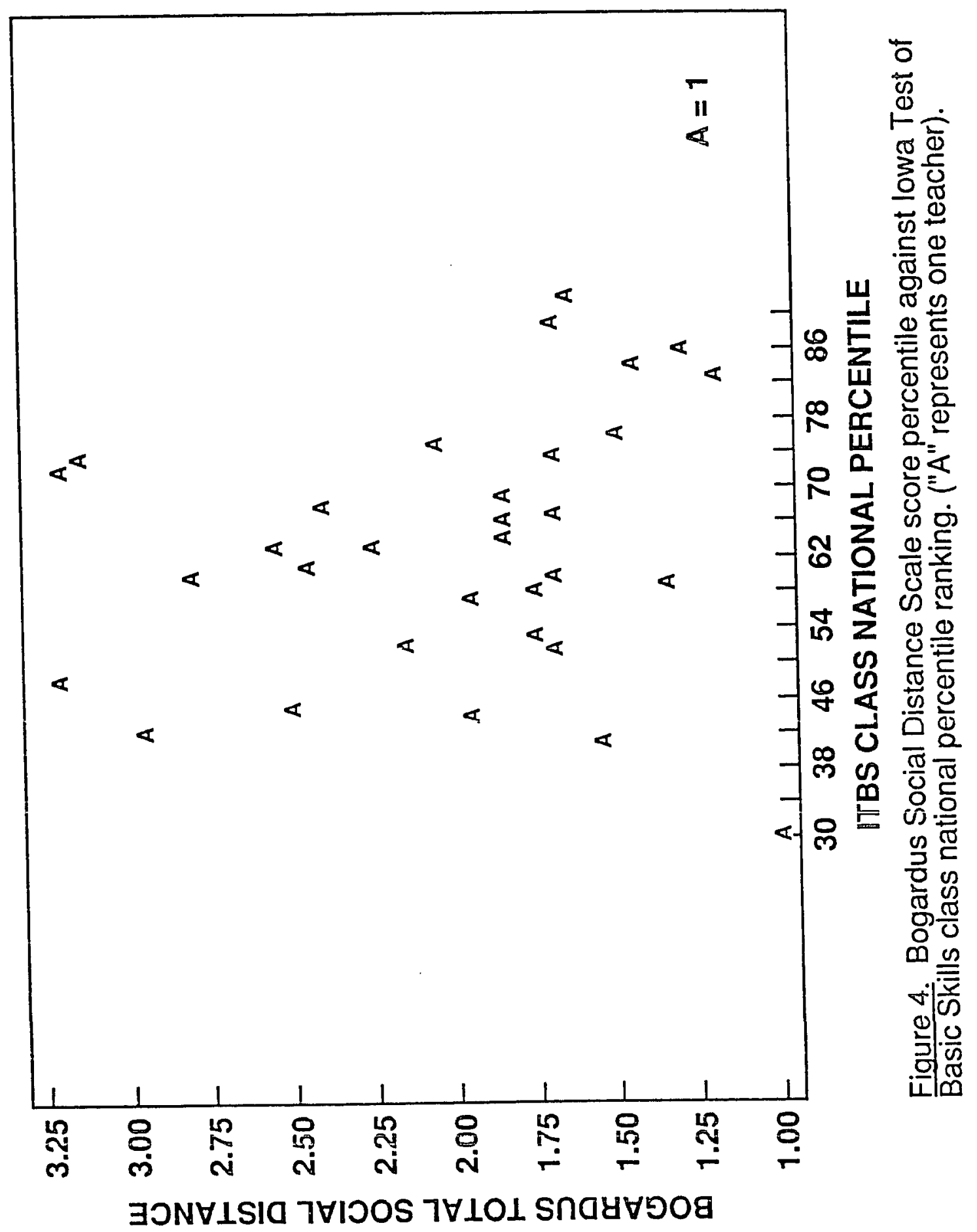


(.086), confidence is lacking in the correlation significance. Since neither correlation was statistically significant, the researcher deferred answering Question \#3.

\section{Summary}

In chapter IV, the three questions related to the hypotheses were introduced, and the results of the study were discussed. In exploring the first question it was found that the correlation was not high enough to indicate that there was confidence that it was a true correlation. Investigation of the second question indicated that the correlation coefficient was in the direction suggested by the literature reviewed in Chapter II. However, the correlation was not statistically stable; with a teacher sample size of 31 , a .361 correlation was needed in order to note with $95 \%$ confidence that the obtained correlation was not due to just sampling error (Best \& Kahn, 1986, p. 342). With respect to the last question, which queried whether teacher acceptance of others or teacher self-concept was more highly related to student achievement, neither correlation was large enough to be significant. Therefore, one correlation cannot be higher than the other. The researcher deferred consideration of this hypothesis because there was insufficient basis for consideration.

Due to the homogeneity of the teacher population with 
respect to education, experience, age and ethnicity, as well as the small socioeconomic and ethnic diversity of the student sample, the results of this study were interpreted as being applicable to this population only. 
CHAPTER V

Summary, Conclusions, and Recommendations

Sun and moon and beat of sea--

Great lands stretching endlessly. Where be bonds to bind the free?

All the world was made for me!

\section{Adelaide Crapsey}

And how am I to face the odds of man's bedevilment and God's

I, a stranger and afraid

In a world I never made.

Alfred Edward Housman

Adelaide Crapsey and Alfred Housman depict two views of the world--the first explodes with enthusiasm; the second shudders in despair. One view sees man as lord of earth, the other as an alien on a friendless planet. There can be little doubt that the way a person views his world affects his capacity for happiness and his ability to contribute effectively to society. And the way one sees oneself greatly determines how he sees his world. This thesis concerned the relationship between how teachers see themselves and students to how students perceive themselves and achieve.

\section{Summary}

The researcher found that there was no statistically reliable correlation between teacher self-concept/acceptance of others and student achievement. However, the direction of the correlation is consistent with those of several other studies. For example, Cheong and wadden (1978) demonstrated 
that dogmatic attitudes towards control (which is attributed to teachers with low self-concept) is correlated to poor pupil-concept. Davidson and lang (1960) found that there is a positive correlation between children's perception of being accepted by their teachers and student academic achievement. Curtis and Altman (1970) found that teachers with high self-concept tended to have students with high self-concepts. Since studies by Coleman et al. (1966), Campbell (1967), and Franks and Dillon (1976) have shown a correlation between student self-concept to student achievement, it logically follows that teachers with high self-concept would have classes with higher student achievement. The research of Aspy and Buhler (1975) is also consistent with this hypothesis.

There are a number of other factors that might have influenced the outcome of this study, which were not examined and could be considered.

1. The rather small variation in the range of scores on the Bogardus scale may explain why the correlation between teacher acceptance of others and student achievement was not higher. According to Best and Kahn (1986) the more homogeneous a group of scores the lower their correlation will be.

2. In order to accurately determine the effect a specific teacher had on a child's achievement, it is perhaps more accurate to measure growth, giving pretests at the beginning of the year and posttests at the end of the 
year. Without measuring growth of achievement during a particular year, it is difficult to discern how much of a child's level of achievement is due to the present teacher or from past teachers. Measurement of growth would be necessary if teachers with high self-esteem were teaching a class with many disadvantaged children, or if teachers with low self-esteem were teaching classes of high achievers. Aspy and Buhler (1975) conducted a study measuring growth in achievement. Although their instruments were more subjective and their sample was small, they found a statistical significant correlation between teacher inferred self-concept and pupil achievement.

3. Environmental factors other than the teacher-pupil interaction could have influenced the results of this study. Variables which could have affected the student achievement, and which were not considered in the statistical analysis for this study include: the student's socioeconomic and ethnic backgrounds, whether the home was single parent, whether the home was peaceful, the position of the child in the family, the age of the child, the primary language spoken in the home, educational level of the parents, parents' self esteem, interest by the parents in the child. All of these and more have been shown to affect a child's attitude and ultimate achievement in school.

4. The negligible correlation between teacher 
self-concept and student achievement can be explained by the experienced background of the teachers. The study of Brenneman et al. (1975) suggested that teacher acceptance of others, followed by teaching experience had a greater influence on student achievement than teacher self-concept. The low correlation might also indicate that a significant fraction of teachers with low self-concept learned behavior which masked their low self-concept. Cantrell et al. (1977), showed that teacher knowledge of behavior principles can affect teacher behavior, and, thus, can override the behavioral implications of teacher self-concept. Teachers can and do learn behaviors that off-set communication of their own feelings (Brophy, 1979). 5. It is conceivable that one year with a given teacher with a given self-concept or attitude was not enough to make a significant impact on a child's achievement. However, the research of Aspy and Buhler (1975) indicated otherwise.

6. The study took place in a midwestern city, which did not have the cultural diversity of the average American city, especially those in California or on the East coast. students who are disadvantaged, as suggested by the study of Davidson and Lang (1960), or who are of a particular cultural background, e.g., Hispanic, may depend more on teacher approval and therefore be more affected by teacher self-concept and acceptance of others. Since this study 
included a student population which was only $12 \%$ minority ( $2 \%$ Hispanic), it may have skewed the statistical results.

6. The teacher sample was composed on a voluntary basis rather than random selection. Thus, even though the study included $84 \%$ of the fourth-grade teachers in the school system, teachers with very low (or high) self-concept/acceptance of others may not have volunteered.

7. Lastly, the low correlation between the teacher variables and student achievement may be explained by the fact that a large majority of the teachers of the selected school district had many years of experience and were well-educated; therefore, those with low self-concept or lack of knowledge of behavior principles may have been eliminated by the school system or dropped out because of lack of success.

\section{Conclusions}

What are the school characteristics that are most related to achievement?

According to Coleman (1966), it appears that variations in the facilities and curriculum of the schools account for relatively little variation in pupil achievement insofar as this is measured by standard tests. The quality of teachers, however, shows a stronger relationship to student achievement.

The interrelations found between children's perception of teachers' feelings, school achievement, behavior and 
socio-economic status are particularly significant (Davidson and Lang, 1960). It seems urgent that teachers be helped to recognize the significance of the feelings which they express toward children, consciously or unconsciously. Some teachers, in addition, may need the help which can only come through a process of self-understanding, in order to avoid or to minimize the expression of negatively-toned feelings toward children, because of their sex, their socio-economic status, their behavior or achievement in school.

The quote by Alfred Edward Housman, which was introduced at the beginning of this chapter, depicts a reluctance to giving one's self over to untried and unknown circumstances. Many young people have been sufficiently humiliated in their previous experiences both in and out of school to make them approach with caution new situations that hold a potential for further self-damage. They have a real need to play things safe, but learning through discovery requires of the student that he risk himself (Combs et al., 1974). As has been discussed above, learning is most likely to take place when the individual feels safe and secure and accepted. According to stavsky (1957), it is important, then, that a warm, friendly, understanding, and encouraging atmosphere characterize all aspects of the student's exploration of knowledge. This requires sympathetic teachers, able to provide support and 
assistance when needed and adept at protecting students from anxiety.

How can teachers communicate attitudes that nourish positive self-concept? Several authors above suggested ways teachers can convey to students that they value them and have faith in their abjlities. Coopersmith and Silverman (1969) believed teachers must strive to be interested in each child and concerned about him or her as an individual. They urged teachers to provide a warm, supportive climate, to genuinely accept children, and to communicate that they sincerely care about each child. Purkey (1970) suggested several ways teachers can communicate an attitude of respect and warmth to students. Teachers should:

- learn the name of each student as soon as possible and use the name often

- share feelings with students

- always be as courteous with students as with adults

- arrange some time for quietly talking alone with each student

- notice and comment favorably on the things that are important to students

Quandt (1973) warned against using embarrassment as a method of punishment since tinis crushes self-concept. He recommended correcting behavior by condemning the specific act rather than the child. 
Can teacher behavior be modified through education to positively influence student self-concept/student achievement? A review of the literature in Chapter II has demonstrated that there is a link between teacher self-concept/acceptance of others and student achievement. coleman et al. (1974) suggested that, through counseling, teacher self-concept can be altered; however, therapeutic results take time. Therapy can also be expensive, and the school district would require a proper counseling staff. In addition, there is greater difficulty in measuring validly and reliably the affective traits than the cognitive skills; thus, proper diagnosis of the degree to which a teacher has poor self-concept or is not accepting of others may be difficult. It is also not known to what extent a teacher can be lacking in these traits, or in the congruence of these traits, and still be an effective teacher. Perhaps this is why, in teacher education, close attention seems to have been given to the cognitive aspects such as grade point average, California Basic Educational Skills Test (C.B.E.S.T.) and/or scores on the National Teacher Exam (N.T.E.). However, since children's self-concept is a crucial determinant for their achievement in school, and teacher attitude and personality make a difference in student self-concept, as much attention as possible should be given to the affective dimensions of teacher education programs, as well as of teacher 
candidates.

A review of the literature in Chapter II also suggests that teacher self-concept/acceptance of others manifests itself in teacher behavior. With respect to this concept, Flanders (1970) and others (Cooper, Thompson and Baer, 1970; Reed and Goetz, 1980) have suggested feasible ways the behavior of teachers, irrespective of their self-concept, can be altered in order to have a positive influence on student self-concept and consequential student performance. Both pre-service and in-service programs can assist in increasing teachers' awareness levels. For instance, their studies suggested that once teachers are aware of aspects of their own teaching, then simple strategies (viewing videotapes of their teaching, coding their own teaching behaviors, verbal and written reminders) can produce changes in teaching behaviors. Studies by Brophy (1979) indicated that making teachers aware of the importance of their attitudes toward student characteristics might be impetus enough for them to begin altering their behavioral communication of those attitudes.

\section{Recommendations}

The researcher respectfully submits the following procedures to follow up and enhance the current study: - The use of a combination factor, as suggested by Cantrell et al. (1977), Fey (1955), and Brownell (1948), such as teacher self-concept, acceptance of others and 
teacher knowledge of behavior principles. This could provide a more reliable prediction for personality characteristics. In conjunction with Fey's study on the relationship between acceptance of others and self-concept, the low correlation between teacher self-concept and student achievement might be a reflection of how the teachers defended themselves interpersonally rather than an indicator of their self-concept. Including a third teacher variable, e.g., classroom control techniques, or teacher experience, in the study, and correlating this with student achievement, could shed light on this possibility.

- The use of pretest scores as covariates. Inserting pretest scores into the design would remove extraneous variation from the posttest scores, thereby increasing measurement precision. Correlations could then be performed on the change in achievement score results, to the teachers' self-concept and acceptance of others.

- The inclusion of other variables in the formal statistical analysis with respect to the students, i.e., primary language, specific ethnic group, disadvantaged status. These could be correlated to teacher self-concept, acceptance of others, and teacher knowledge concerning behavior principles.

- The conducting of identical studies at different grade levels and then comparing the correlations. This would give more reliable and conclusive evidence about the 
age level at which attention to self-concept might have the greatest influence on student achievement.

- The conducting of identical studies in different regions of the country, and making a comparison analysis. A more heterogeneous teacher population and/or student population could give different results to the study.

- The entering of achievement scores, ethnic and socio-economic information, age, etc. of each individual student into the database, rather than using a class mean; finding the correlation between the teacher variables and the achievement growth for individual students. A comparison study could then be made with respect to the minority status and socio-economic background of the children with the teacher variables.

- The finding and comparison of the correlation of the scores for each subgroup provided on the achievement test, i.e., vocabulary, reading, mathematics, work skills, social studies skills with the teacher variables. One could then determine if there is a higher correlation between the teacher variables with one subgroup than with another. - The conducting of a longitudinal study, using the same variables, in a school system, i.e., Japan, Switzerland, where the children may have a given teacher for a number of years. This would help to minimize the influence of previous teachers on a student's 
self-concept/achievement.

This could also present a clearer indication of the effect a particular teacher with a particular attribute might have on children over a given periogd of time.

- The testing of the relationship between teacher self-concept and student achievement by using an instrument which measures inferred self-concept, as did Aspy and Buhler (1975), rather than one which uses a self-report technique such as the Tennesee self-Concept Scale. In accordance with Parker's study in 1966, instruments which measure inferred self-concept represent a more accurate and realistic appraisal of perception of self than do self-reports.

In sum, it is believed that a number of intriguing questions were explored in this inquiry, and that this project could serve as a model for further research into the effectiveness of teaching. Extending this study by incorporating the recommendations given above could have profound implications for teacher education programs. 
REFERENCES

Adler, A. (1964). Social Interest. New York: Putnan.

Aspy, D. N., \& Buhler, J. H. (1975, July/August). The effect of teachers' inferred self concept upon student achievement. The Journal of Educational Research, $\underline{68}(10), 386-89$.

Berger, E. M. (1952). The relationship between expressed acceptance of self and expressed acceptance of others. Journal of Abnormal and Social Psychology, 47, 778-782.

Best, J.W. \& Kahn, J.V. (1986). Research in Education (5th ed.). New Jersey: Prentice-Hall.

Bogardus, E. S. (1966), A social distance scale. Sociology and Social Research, 17, 265-271.

Bogardus, E.S. (1967). A Forty Year Racial Distance Study. Los Angeles, California: University of Southern California. 
Brenneman, O. N., Willower, D. J., Lynch, P. D. (1975). Teacher self-acceptance, acceptance of others, and pupil control ideology. Journal of Experimental Education, 44, 14-17.

Brophy, J. (1979). Teacher Behavior and Its Effects. College of Education, Michigan state University: The Institute for Research on Teaching.

Brownell, W. A. (1948). Criteria for learning in educational research. Review of Educational Research, 8, 106-112.

Campbell, P. R. (1967). School and Self Concept. Educational Leadership, 24, 510-513.

Cantrell, R. P., Stenner, A. J., \& Katzenmeyer, W. G. (1977). Teacher knowledge, attitudes, and classroom teaching correlates of student achievement. Journal of Educational Psychology, $69(2), 172-179$.

Cheong, G. S., \& Wadden, E. P. (1978). The relationship between teachers' experimental dogmatic attitudes and their pupils' self-concept. Alberta Journal of Educational Research, $\underline{24}(2), 121-125$. 


\begin{abstract}
Coleman, J. S. (1966). Equality of educational opportunity. National Center for Educational Statistics (DHEW), Washington, D.C.
\end{abstract}

Combs, A. W., Blume, R. A., \& Wass, H. L. (1974). The Professional Education of Teachers - A Perceptual View of Teacher Preparation. Boston: Allyn and Bacon, Inc.

Congdon, C. S. (1958). Self theory and chlorpromazine treatment. Dissertation Abstracts, 19, 2654 .

Cooper, M., Thompson, C. L. \& Baer, D. M. (1970). The experimental modification of teacher attending behavior. Journal of Applied Behavioral Analysis, 3 , $153-157$.

Coopersmith, S., \& Silverman, J. (1969). How to enhance pupil self-esteem. Today's Education, $\underline{58}(4), 28-29$.

Curtis, J. \& Altman, H. (1977). The relationship between teachers' self concept and the self concept of students. Child Study Journal, I(1), 17-27. 
Davidson, H.H. \& Lang, G. (1960). Children's perceptions of their teachers' feelings toward them related to self-perception, school achievement, and behavior. Journal of Experimental Education, 29, 107-118.

Darrigrand, G. E., \& Gum, M. F. (1973). A comparison of the effects of two methods of developmental guidance on the self-concept, peer relationships and school attitudes of second grade children. In G. Dean Miller (Ed.), Additional Studies in Elementary School Guidance: Psychological Education Activities Evaluated (pp. 63-111). St. Paul: Minnesota State Department of Education.

du Vall, E. W. (1950). Parent-child social distance. Sociology and Social Research, 2I, 458-463.

Driscoll, A. \& Reynolds, R. (1980). Teachers' Self-perceptions and descriptions of students for whom they hold positive attitudes. Journal of Classroom Interaction, $19(2), 2-8$.

Fey, W. F. (1955). Acceptance of others and its relation to acceptance of self and others: A revaluation. Journal of Abnormal and Social Psychology, 50, 274-276. 
Flanders, N. (1970). Analyzing Teacher Behavior.

Reading, Massachusetts: Addison-Wesley.

Franks, D. D., \& Dilion, S. (1976). The effects of open schools on children: An evaluation. Final Report. Denver: Department of Sociology, University of Denver.

Glasser, W. (1969). Schools Without Failure. New York: Harper \& Row, Publishers.

Hartley, E. L. \& Hartley, R. E. (1952). Fundamentals of Social Psychology. New York: Alfred A. Knopf.

Haynes, N. M., Comer, J. P., Hamilton-Lee, M., Boger, J. M., \& Rollock, D. (1987). An analysis of the relationship between children's self-concept and their teachers' assessments of their behavior: Implications for prediction and intervention. Journal of School Psychology, 25, 393-397.

Kash, M. M. Borich, G. D. \& Fenton, K. S. (1976). teacher behavior and pupil self-concept. Final Report. Denver: Department of Sociology, University of Denver. 
Mccallon, E. L. (1967). Self-ideal discrepancy and correlates sex and academic achievement. Journal of Experimental Education, 35, 45-49.

Mead, G. H. (1968). Mind, self and society. In Gordon and Gregen (Eds.), The Self and Social Action: Vol. I (pp. 137-144). New York: Wiley.

Miller, J. P. (1976). Humanizing the open Classroom. New York: Praeger.

Nunnelly, K. G. (1968). The use of multiple therapy in group counseling and psychotherapy. Unpublished doctoral dissertation, Michigan State University, East Lansing, Michigan. (University Microfilms No. 69-11, 139)

Omwakee, K. T. (1954). The Relationship between acceptance of self and acceptance of others shown by three personality inventories. Journal of consulting Psychology, 18, 443-446.

Parker, J. (1966). The relationship of self report to inferred self concept. Educational and Psychological Measurement, 16, 691-700. 
Purkey, W. W. (1970). Self concept and School

Achievement. Englewood Cliffs, New Jersey: Prentice-Hall.

Quandt, I. (1973). Self-Concept and Reading.

Bloomington: ERIC Clearinghouse on Reading, Indiana University.

Reed, S. \& Goetz, E. (1980). Encouraging ethical behavior through teacher verbal attention. young Chilaren, $\underline{35}, 51-57$.

Rogers, C.R. (1961). On Becoming a Person: A Therapist's View of Psychotherapy. Boston: Houghton Mifflin.

Roiâ, G.H. \& Fitts, W.H. (1988). Tennessee Self-Concept Scale. Revised manual, Western Psychological Services, Los Angeles.

Samuels, S. E. (1977). Enhancing Self-Concept in Early Childhood. New York: Human Sciences Press.

sartain, A. I. \& Bell, H. V., Jr. (1950). An evaluation of the Bogardus scale of Social Distance by the method of equal-appearing intervals. Journal of Social Psychology, 29, 85-91. 
Schultz, D. (1986). Theories of Personality (3rd ed.). California: Brooks/Cole.

Sheerer, E. T. (1949). An analysis of the relationship between acceptance of and respect for the self and acceptance of and respect for others in ten counseling cases. Journal of Consulting Psychology, 13, 164-175.

Sherif, M. \& Sherif, C. (1956). Fundamentals of Social Psychology. New York: Harper \& Brothers.

Staines, J. W. (1958, June). The self picture, as a factor in the classroom. British Journal of Educational Psychology, 28, 97-111.

stanwyck, D. J., \& Garrison, W. M. (1982). Detection of faking on the Tennessee Self-Concept Scale. Journal of Personality Assessment, 46, 426-43I.

Statistical Abstract of the U.S. (1988). Bureau of the Census (108th Ed., 1987). Washington, D.C.

Stavsky, W. H. (1957, oct.). Using the insights of psychotherapy in teaching. The Elementary school Journal, p. 32 . 
Tyler, L. I. (1964). The concept of an ideal teacher-student relationship. Journal of Educational Research, 58, 112-117.

Vygotsky, L. S. (1962). Thought and Lanquage. Cambridge: MIT Press.

Wright, B. D. \& Stone, M. H. (1979). Best Test Design. Chicago: Mesa Press.

Wylie, R. C. (1969). The present status of self theory. In E. F. Borgatta \& W. E. Lambert (Eds.), Handbook of Personality Theory and Research (pp. 239-252). Chicago: Rand McNally. 
Appendix A

Teacher's Questionnaire

Teacher's Name

Teacher's Assigned School

Number of Graduate Units Beyond Bachelor's

Countries Visited outside of the United States

Major Field of Study for Bachelor's

Number of Years of Teaching Experience 
Appendix B

Tennessee Self-Concept Scale

William H. Fitts, Ph.D. 
PLEASE NOTE

Copyrighted materials in this document have not been filmed at the request of the author. They are available for consultation, however, in the author's university library.

$80-91$

University Microfilms International 


\section{Appendix D \\ Human Subjects Protocol for Research}

Purpose and Background

Although home experiences have a profound effect on the self-concepts children bring with them to school, school experiences are also extremely significant in the development of student self-esteem. Next to parents, teachers probably have the most pervasive effect on children's self-concepts, especially on their beliefs about their own academic abilities. Some evidence for this can be found in research indicating that teacher attitudes about student abilities have strong effects on student performance.

This study will determine the interrelationship between teachers' self-concept, acceptance of others and student achievement. The results wili be analyzed with respect to minority and disadvantaged students. It will suggest the necessity for developing programs which promote good teacher self-concept and acceptance of others in order to reduce the dropout rate for students. Justification for study Involving Humans

This study requires the participation of humans, since self-concept and attitudes involving acceptance of others cannot be measured in animals, and since no appropriate archival data are available. 
Specific Aims of Research

The author will address the following research questions :

a. What is the relationship between teachers' self-concept and the level of achievement of their students?

b. What is the relationship between teachers' acceptance of others and the level of achievement of their students?

c. How does the magnitude of the correlation of teachers' self-concept and achievement of others compare in its influence on the magnitude of the correlation to student achievement?

The researcher hypothesizes the following in null form:

a. student achievement is not a function of teacher self-concept.

b. Teachers' acceptance of others will not be positiveIy related to student achievement.

c. There will not be a higher correlation between acceptance of others and student achievement than between self-concept and student achievement.

Method

a. Procedures to be performed

1) AY 88-89 fourth grade teachers will be sent a letter in October, explaining the purpose of the study and asking for their cooperation. They will be asked to 
indicate which days and times would be convenient for them to participate in the study.

2) Meetings will be held with teachers within their respective schools. At these meeting, the confidentiality procedures as well as the testing procedures will be explained to the teachers, and they will be asked to read and sign the consent form. Teachers will then be administered the Tennessee self-concept scale and Bogardus' Social Distance Scale

3) Permission will be requested from the school district to allow the researcher access to the 88-89 fourth grade students' standardized achievement tests as well as information in the students' cumulative folders. Information from the cumulative folders will be used to determine the ethnic, and socio-economic background of the students.

4) Researcher will determine the correlations between the scores of the two questionnaires, as well as the correlation between the scores of the two questionnaires and the indices of the students' achievement.

b. Special procedures None

c. Frequency and duration of each procedure The one meeting for the teachers will last about one hour: explanations will take about 10 minutes, The 
Tennessee Self-Concept scale will take 20 minutes, and the Social Distance scale will take 15 minutes.

d. Location of study

The study will take place in empty classrooms within the individual schools of the sample school district. The principal of each school will be contacted prior to the meetings in order to make arrangement to use a particular classroom.

e. Mechanisms for maintaining confidentiality

The researcher will assign identifying code letters to all teacher subjects and code numbers to their respective students which will be registered on a listing. These identifying numbers will be noted on the teachers' test sheets and on the analysis sheets. The analysis sheets will reflect the results of the Tennessee Self-Concept scale and the Bogardus Social Distance Scale for the teachers. They will also register the ethnic and socio-economic background of the students, as well as their fourth grade standardized achievement scores. The list of subjects' names with their identifying codes, the test sheets and the analysis sheets will be kept in a locked drawer in the investigator's office. All dissemination of the results of this work (journal articles, conference papers, class presentations, etc.) will describe group patterns, means and differences. Where illustrative examples are drawn from individual situations, 
investigator for this study at this time, and no standard treatments are being withheld.

5. The results from this study may be published, but any information from this study that can be identified with me will remain confidential and will be aisclosea only with my permission or as required by law.

6. I understand that any questions about my participation in this study will be answered by Sandra McMahan (415 723 9855). Complaints about the procedures may be presented to Dr. Amy Strage, Professor of Teacher Education (408 924 3715 ) or Dr. Sarena Stanford, Associate Academic Vice President for Graduate studies (408 924 2480). 7. My consent is given voluntarily without being coerced; I may refuse to participate in this study or in any part of this study, and I may withdraw at any time, without prejudice to my relations with California state college at San Jose or the Cedar Rapids community Schools. 8. I have received a copy of this consent form for my file. 
I HAVE MADE A DECISION WHETHER OR NOT TO PARTICIPATE. MY SIGNATURE INDICATES THAT I HAVE READ THE INFORMATION PROVIDED ABOVE AND THAT I HAVE DECIDED TO PARTICIPATE.

date subject's signature investigator's signature 
Appendix $\mathrm{E}$

Cover Letter

January 17,1990

Fourth Grade Teachers of the (name of schooi system)

Dear

This is to request your voluntary participation in a research project which has been approved by the (name of school system. The project is to investigate the interrelationship between teachers' self-concept, acceptance of others and the achievement of elementary school children. The results of this study should further our understanding of how teacher attitude and behavior affect student achievement, and ultimately the students' attitudes toward learning and the dropout rate, particularly among minority, bilingual and disadvantaged students. Furthermore, the results of the study can have implications for future teacher education.

You will be asked to take the Tennessee Self-Concept scale and the Bogardus Social Distance Scale. This should take less than one hour of your time. Please be assured that all dissemination of the resuits of this work, i.e., journal articles, conference papers, class presentations, the report to the (name of school system), will describe group means and differences. The teacher's identity will be removed, and names will not even be used on the answer sheets of the two scales. I will be coming to your individual schools sometime in early February, 1990, and will accommodate the time that best suits you. If before that time you have any questions about this project, please contact (name of Director of Research).

I am looking forward to meeting you in February. Thank you in advance for your cooperation.

sincerely yours,

Sandra G. McMahan San Jose State University 


\section{Appendix F \\ Consent Form}

\section{RESPONSIBLE INVESTIGATOR: Sandra G. McMahan}

TITLE OF PROJECT: "Teachers: Self=Concept, Acceptance of Others and the Achitvement of Elementary School Children" I have been asked to participate in a research study that is investigating the interrelationship between teachers: self-concept, acceptance of others and the achievement of elementary school children. The results of this study should further our understanding of how teacher attitude and behavior affect student achievement. This, in turn, can affect the attitudes toward learning, and the resultant dropout rate particularly amongst minority, bilingual and disadvantaged students.

I understand that:

1. I will be asked to take the Tennessee self-Concept scale (20 min.) and the social Distance scale (15 min.). 2. There are no perceived risks to this study. 3. The possib:e benefit of this study to me is, based on the results, school systems may provide programs which will enhance teachers' self concept and engender greater self-awareness of teacher behavior. As a by-product, student achievement may improve and the student drop-out rate may diminish.

4. There are no alternative procedures determined by the 
investigator for this study at this time, and no standard treatments are being withheld.

5. The results from this study may be published, but any information from this study that can be identified with me will remain confidential and will be disclosed only with my permission or as required by law. 6. I understand that any questions about my participation in this study will be answered by Sandra McMahan (415 723 9855). Complaints about the procedures may be presented to Dr. Amy Strage, Professor of Teacher Education (408924 3715 ) or Dr. Serena Stanford, Associate Academic Vice President for Graduate Studies (408 924 2480). 7. My consent is given voluntarily without being coerced; I may refuse to participate in this study or in any part of this study, and I may withdraw at any time, without prejudice to my relations with California state college at San Jose or the Cedar Rapids Community Schools. 8. I have received a copy of this consent form for my file. 
I HAVE MADE A DECISION WHETHER OR NOT TO PARTICIPATE. MY SIGNATURE INDICATES THAT I HAVE READ THE INFORMATION PROVIDED ABOVE AND THAT I HAVE DECIDED TO PARTICIPATE.

date subject's signature investigator's signature 


\section{Appendix G \\ Instructions for the TSCS and the Bogardus Social Distance Scale}

\section{Tennessee Self-Concept scale}

on the top line of the separate answer sheet, fill in your name and the other information except for the time information in the last three boxes. You will fill in these boxes later. Write only on the answer sheet. Do not put any marks in this booklet.

The statements in this booklet are to help you describe yourself as you see yourself. Please respond to them as if you were describing yourself to yourself. Do not omit any item. Read each statement carefully, then select one of the five responses listed below. On your answer sheet, put a circle around the reponse you chose. If you want to change an answer after you have circled it, do not erase it but put an $x$ mark through the response and then circle the response you want.

When you are ready to start, find the box on your answer sheet marked time started and record the time. When you are finished, record the time finished in the box on your answer sheet marked time finished.

As you start, be sure that your answer sheet and this booklet are lined up evenly so that the item numbers match each other. 
Remember, put a circle around the response number you have chosen for each statement.

$\begin{array}{ccccc}\text { Completely } & \text { Mostly } & \text { Partly } & \text { Mostly } & \text { Completely } \\ \text { False } & \text { False } & \text { False } & \text { True } & \text { True } \\ & \& & & \end{array}$

Partly

True

$\begin{array}{lllll}1 & 2 & 3 & 4 & 5\end{array}$

You will find these response numbers repeated at the top of each page to help you remember them.

\section{Bogardus Social Distance Scale}

You are urged to give yourself as complete freedom as possible. In fact, the greater the freedom you give yourself, the more valuable will be the results. Use only check marks or crosses.

Seven kinds of social contacts are given. You are asked to give in every instance your first feeling reactions. proceed through the scales without delaying. The more you "stop to think," the less valuable will be the results.

Please do not discuss either scale with anyone until everyone has finished. 
Appendix $\mathrm{H}$

Political and Economic Distance Definitions

Capitalist - one who upholds capitalism - the economic system in which all or most of the means of production and distribution, as land, factories, railroads, etc. are privately owned and operated for profit, originally under fully competitive conditions: it has been generally characterized by a tendency toward concentration of wealth, and, in its later phase, by the growth of great corporations, increased governmental control, etc.

Marxian Socialist - one who ascribes to a political party (Socialist Party) based on the principles of socialism advocated by Marx.

Socialist - one who upholds the theory or system of the ownership and operation of the means of production and distribution by society or the community rather than by private individuals, with all nembers of society or the community sharing in the work and the products.

Fabian Socialist - one who ascribes to a Fabian Society an organization of English socialists, established in 1884, aiming to bring about socialism by gradual reforms rather than drastic means. 
Communist - one who holds the doctrines of, or practices, communism - an economic theory or system of the ownership of all property by the community as a whole. The theory or system of the ownership of all means of production (and distribution) by the community or society, with all members of the community or society sharing in the work and the products.

Cooperator - A member of a cooperative society - an organization, as for the production or marketing of goods, owned collectively by members who share in its benefits.

Fascist - a member of the of the Fascisti - characterized by rigid one-party dictatorship, forcible suppression of the opposition, the retention of private ownership of the means of production under centralized governmental control.

Isolationist - A person who believes in or advocates isolation; a person who wants his country to take no part in international alliances, leagues, etc.

Iiberal - one who favors reform or progress, as in religion, education, etc.: specifically, favoring political reforms tending toward democracy and personal freedom for the individual; progressive. 
syndicalist - one who believes in a theory and movement of trade unionism, originating in France, in which all means of production and distribution would be brought under the control of federations of labor unions by the use of direct action, such as general strikes.

Townsendite - An adherent of the Townsend Plan, a social insurance measure proposed by Dr. Francis E. Townsend, according to which all wage earners would retire at the age of sixty and receive a monthly pension from the U.S. government.

New Dealer - An advocate of the economic and political principles and policies adopted by President Franklin D. Roosevelt and his associates to advance the economic and social welfare of the American people.

Prohibitionist - one who is in favor of prohibiting by law the manufacture and sale of alcoholic beverages. 
量

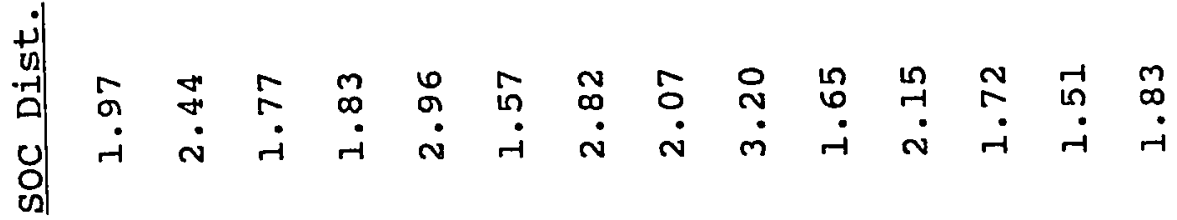

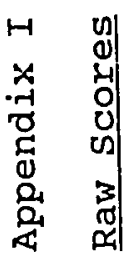

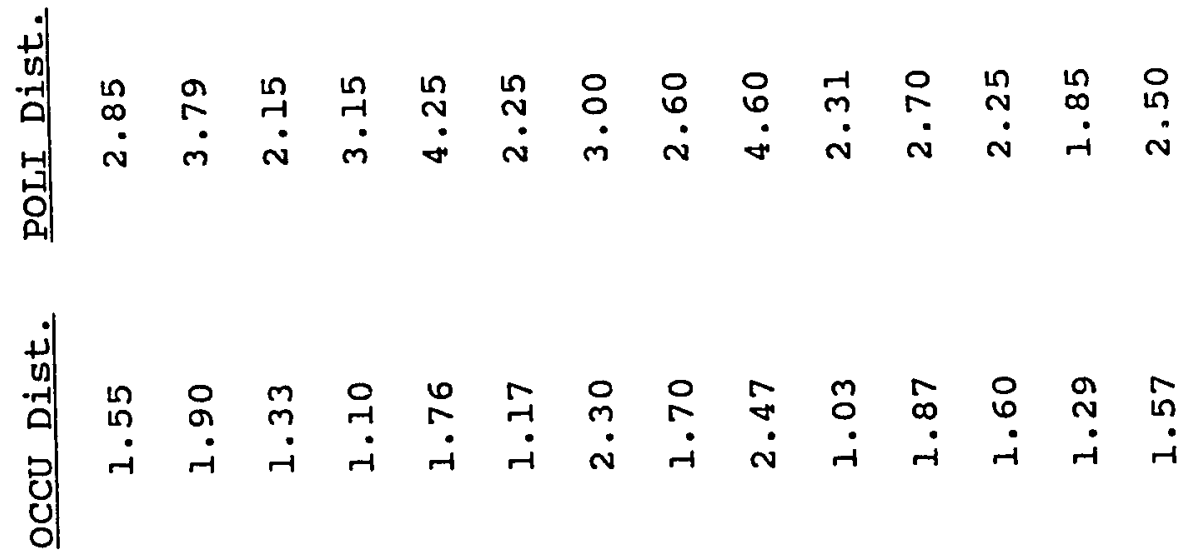

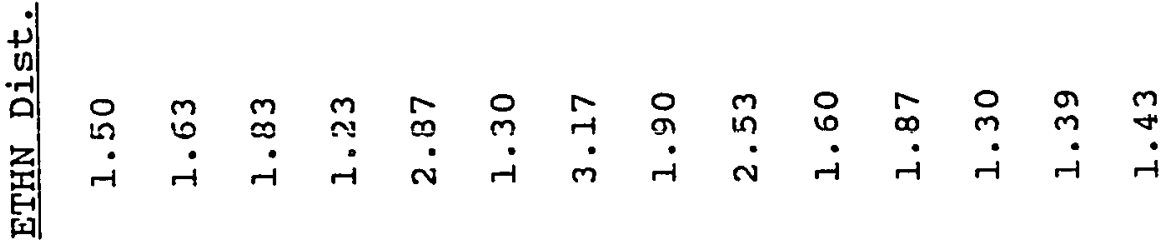

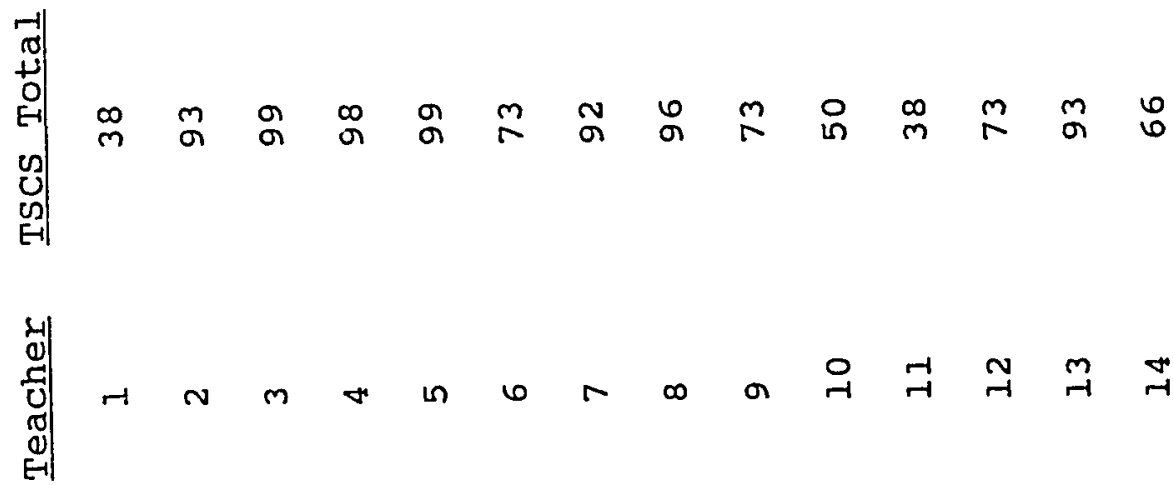


品

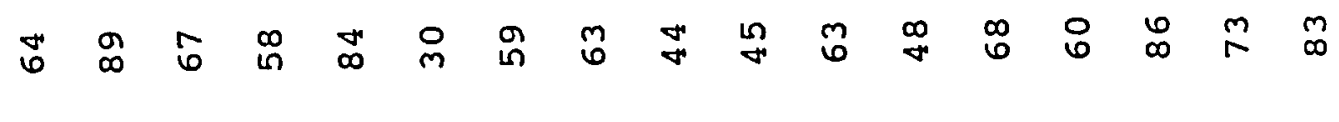

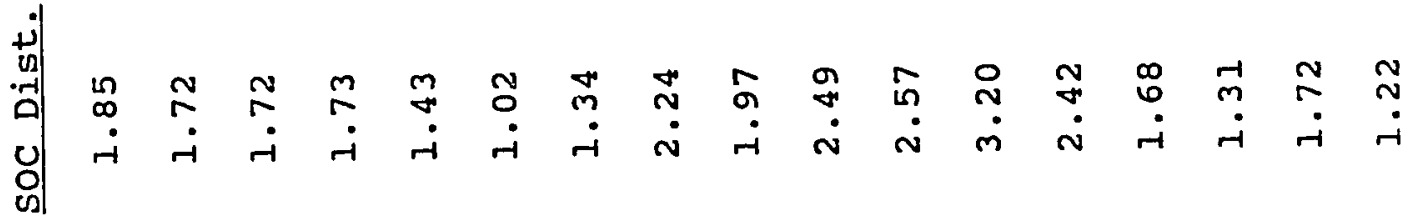

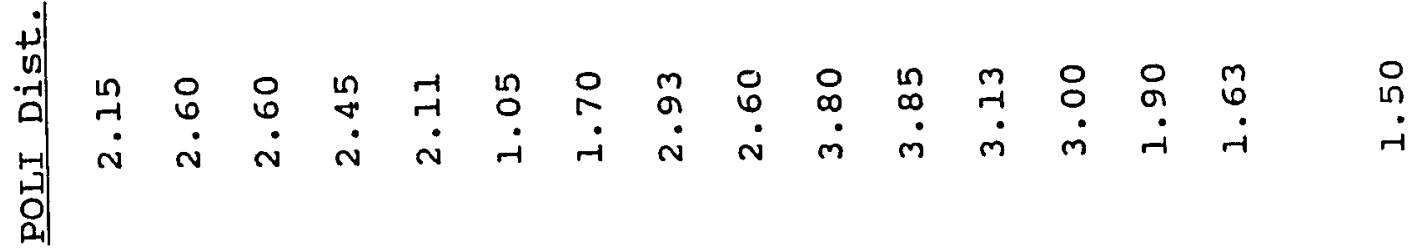

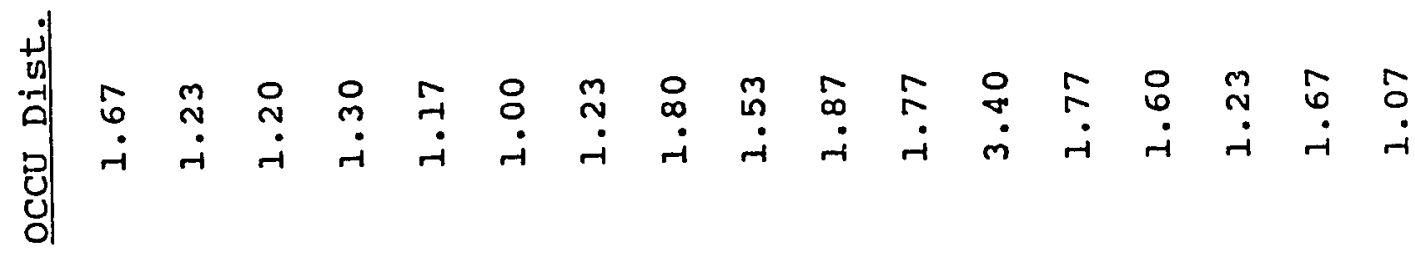

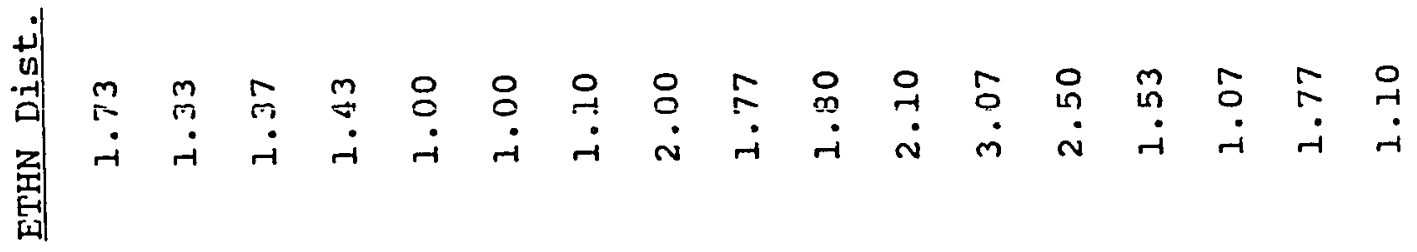

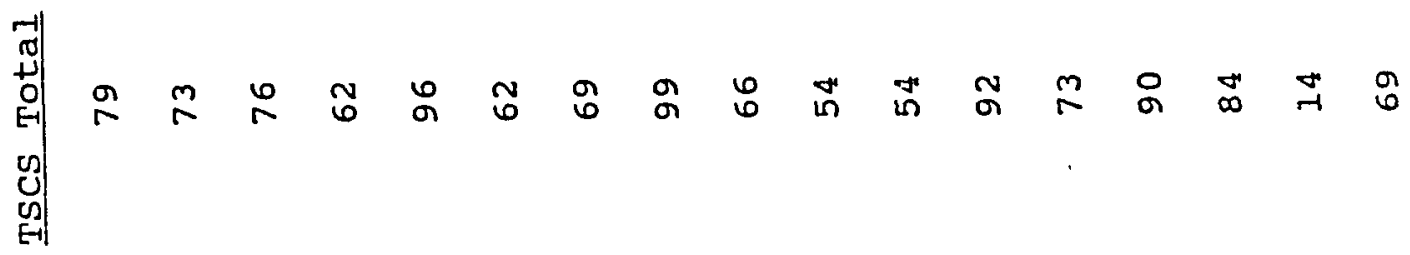

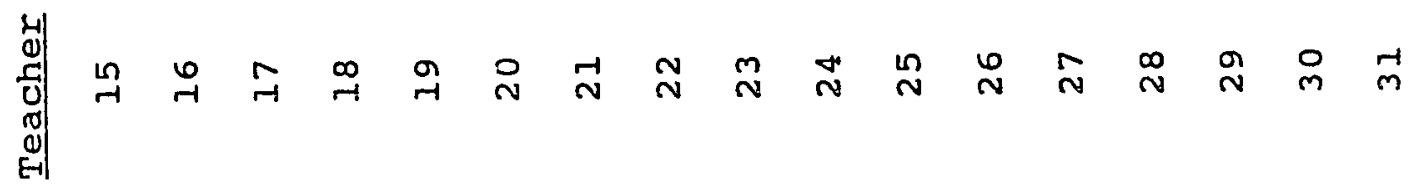

